\title{
NIAGARA MOHAWK v. FPC: HAVE PRIVATE WATER RIGHTS BEEN DESTROYED BY THE FEDERAL POWER ACT?
}

Charles P. Schwartz, Jr. $\dagger$

\section{INTRODUCTION}

For eons water has flowed over Niagara Falls. At this late date the extent to which this water power is private property is an open question. This is true not only of Niagara, but also of all other navigable rivers in the United States.

This question may finally be answered in the case of Niagara Mohawk Power Corp. v. FPC, ${ }^{1}$ in which the FPC contended that the Federal Power Act ${ }^{2}$ erased all state created property interests in water power. The Court of Appeals for the District of Columbia found exactly to the contrary, one judge dissenting, and the Supreme Court has granted certiorari. This article suggests that the decision below is only partially correct.

If the FPC is correct, millions of dollars long thought to exist as values attributable to water rights will be destroyed in one fell swoop. In this case alone at least $\$ 5,780,000$ is ultimately involved. ${ }^{3}$ The problems raised are difficult and complex. The legislative history is sparse, and a maze of judicial opinions must be mastered in order to sensibly analyze the Power Act. And since the FPC proposal would wipe out interests in water, long thought to constitute property, this analysis must be tempered with the sensitivity and fairness necessary for a just result.

The Federal Power Act requires regulation and licensing of all water power projects using navigable waters. ${ }^{4}$ At the expiration of

$\dagger$ A. B. 1945, University of Chicago; LL. B. 1950, Harvard University. Teaching Fellow, Harvard Law School.

1. 202 F.2d 190 (D.C. Cir. 1952), reversing 9 F.P.C. 228 (1950), cert. granted, 345 Uं.S. 955 (1953).

2. 49 StaT. 863 (1920), as amended, 16 U.S.C. $\$ 791$ (a) et seq. (1946). This article will be concerned principally with Part I of the Act, which relates only to water power licensees. Title II of the Public Utility Act of 1935, 49 STAT. 838 (1935), 16 U.S.C. 796 (1946), is the Federal Power Act, and $\$ 212$ provided that the original $\$ \$ 1-29$ of the Federal Water Power Act, 41 STAт. 1077 (1920) should constitute Part I. The licensee provisions of the Federal Power Act remain substantially as they were originally enacted in 1920 .

3. See note 52 infra.

4. The matters outlined here are all discussed in much greater detail below. 
each license the United States may purchase or "recapture" the project upon payment of the licensee's "net investment" in it. Under the Act this net investment is roughly the cost of the project less certain deductions. ${ }^{5}$ The principal deductions are earnings of the project in excess of a "fair return" on its costs.

Of course, earnings are commonly thought to be receipts less operating expenses and overhead. In the present case the FPC refused to allow as an operating expense, rentals for water rights, payment of which was required by state property law. The commission asserted that the Power Act destroyed such water rights. Since the licensee needed only his federal license to use the water, the rentals were unnecessary and thus not valid operating expenses. Consequently the amount paid as rent was to be added to reported earnings. Presumably it follows that the FPC would also disallow as a project cost any expenditure made to acquire a fee interest in water rights. Nor would it seem to make any difference whether the moneys paid were for the water rights severed from the land, or constituted that part of the rent or cost of land attributable to attached water rights.

The Federal Government does not now seek to recapture Niagara's project, but a licensee's net investment in his project must be determined prior to recapture since it is also used for other purposes. For instance in this case the question involves setting up the amortization reserves required by the Act. ${ }^{6}$ This reserve includes excessive earnings made after twenty years of operation of a project and will be credited against the price to be paid on recapture by the United States.

One last word of introduction; it must, of course, be realized that interests in flowing water cannot be termed "property" in the same way as can ownership of land, bonds, or automobiles.

"For water is a movable, wandering thing, and must of necessity continue common by the law of nature; so that I can only have a temporary, transient, usufructuary, property therein." 7

In addition, the many limitations that have been imposed upon this right to use water power ${ }^{8}$ must be considered in describing any set of water rights.

5. Section 3(13), 16 U.S.C. $\$ 796(13)$ (1946).

6. Section $10(d), 16$ U.S.C. $\$ 803$ (d) (1946). In addition to serving as the recapture price ( $\$ 10(\mathrm{~d}), 16$ U.S.C. $\$ 803(\mathrm{~d})(1946)$ ), the net investment serves: as the rate base for any rates fixed by the FPC ( $\$ 20,16$ U.S.C. $\$ 813$ (1946)); the basis for determining the rental to be paid by the United States in the event of a temporary taking of the project during a national emergency $(\$ 16,16$ U.S.C. $\$ 809$ (1946)) ; and the price to be paid by the United States at a court sale in the event of forfeiture of the license ( $\$ 26,16$ U.S.C. $\$ 820$ (1946)).

7. 2 Bu. Comm. *18.

8. As Mr. Justice Jackson has said: “. . . that a closed catalogue of abstract and absolute 'property rights' in water hovers over a given piece of shore land, 


\section{Past and Present Use of Ntagara Water}

The Niagara Mohawk Power Corporation uses all water that the United States permits to be diverted from the Niagara River (near the Falls) under the International Boundary Waters Treaty of $1910 ;^{9}$ this amounts to 19,725 c.f.s. ${ }^{10}$ Since 1921 this diversion has been made under a fifty year license issued in that year by the FPC pursuant to the Power Act. However, a more detailed account of the use of Niagara water will help place this case into its proper perspective.

The relevant history starts in 1891 when a predecessor of Niagara ${ }^{11}$ was planning to build a power plant on the river above the Falls. This planning culminated in the Adams Plant, which now takes water from the river, runs it through the plant and discharges it via a tunnel into the river at a point below the Falls. ${ }^{12}$

good against all the world, is not in this day a permissible assumption. We cannot start the process of decision by calling such a claim as we have here a "property right'; whether it is a property right is really the question to be answered. Such economic uses are rights only when they are legally protected interests. Whether they are such interests may depend on the claimant's rights in the land to which he claims the water rights to be appurtenant or incidental; on the navigable or nonnavigable nature of the water from which he advantages; on the substance of the enjoyment thereof for which he claims legal protection; on the legal relations of the adversary claimed to be under a duty to observe or compensate his interests; and on whether the conflict is with another private riparian interest or with a public interest in navigation." United States v. Willow River Power Co., 324 U.S. 499, 502 (1945).

At the outset it should be noted that whereas the eastern part of the United States follows the system of "riparian rights," giving each owner along a river the right to use water power so long as he returns the water at the downstream edge of his property, most of the western states follow a system of "prior appropriation," which sometimes permits certain owners along a river to use water power to the exclusion of other upstream and downstream owners. The problem covered by this article is unaffected by the difference between these systems. The terms "riparian" and "water rights," and their derivatives, will be used to refer to both systems.

9. The treaty limited diversion from the United States side of the river to 20,000 c.f.s. (cubic feet per second). 36 STAT. 2448, 2450 (1909).

10. Niagara also diverts another 12,500 c.f.s. by authority of the FPC and pursuant to wartime agreements between the United States and Canada providing for "emergency" diversions.' 55 STAT. 1276, 1380 (1941). Both diversions will in effect be superseded by a 1950 treaty with Canada. TREATIES \& OTHER INT'L AcTs SER. 2130 (1950). This last pact limits diversion only by the requirement that a specific minimum amount of water be allowed to flow over the Falls.

11. Throughout this article "Niagara" will usually refer to the present licensee, Niagara Mohawk Power Corporation, or its immediate predecessor, the Niagara Falls Power Company, which was merged into Niagara Mohawk in 1950. "Niagara" will also, where required by the context, refer to certain predecessors of Niagara Falls Power Company which were consolidated in 1918 to form that company. The variety of corporate entities is not, however, of substantive importance in this case, except where noted. The pertinent corporate genealogy is found in Niagara Falls Power Co. v. FPC, 137 F.2d 787 (2d Cir. 1943), and in the decision below, Niagara Mohawk Power Corp. v. FPC, supra note 1.

12. This plant effected the first large scale use of water power at Niagara to generate electricity. It was owned, prior to 1918, by the original Niagara Falls Power Company, one of the corporations consolidated in 1918 to form the company of the same name. This latter company was the immediate predecessor of Niagara Mohawk. 
Closer to, but still above, the Falls was the intake for a "Hydraulic Canal" owned by another predecessor of Niagara. ${ }^{13}$ This canal runs from the river into a reservoir or basin from which water was drawn by a number of companies who ran it through their manufacturing plants located near the top of the river banks. They returned the water to the river by letting it flow over these banks. Many years ago the last of these plants was torn down. Water is now taken from the canal basin only by Niagara, who runs it through penstocks to its Schoellkopf Plant at the base of the river banks below the Falls. ${ }^{14}$

International Paper Water Rights:-The first of the two sets of water rights involved in this case are those of the International Paper Company. It operates a plant on the river above the Falls right next to Niagara's Adams Plant. In the 1890's, by a series of transactions International received from a predecessor of Niagara the right to divert up to 730 c.f.s. so long as it paid specified annual rentals. $^{15}$ It was to return this water to the river via the Adams Plant tunnel.

In 1918 the Niagara Falls Power Company was formed by a consolidation of local power companies. ${ }^{16}$. As part of this transaction it was decided that the Schoellkopf Plant below the Falls would be enlarged to utilize all of the 20,000 c.f.s. given to the United States by the 1910 Treaty. The Adams Plant above the Falls was to be

13. Niagara Falls Hydraulic Power and Manfacturing Company, later known as the Hydraulic Power Company of Niagara Falls. It was consolidated into the Niagara Falls Power Company in 1918.

14. The Schoellkoepf Plant is the most modern unit of the Niagara project. It was built in three sections: Section A (built 1903-14), Section B (built 1918-20) and Section $C$ (built 1921-24). A predecessor plant built in 1881 has long since been torn down. Sections $A$ and $B$ obtain their water from intakes located at the canal basin, from which it is dropped via penstocks through the turbines and discharged into the Niagara River. Section $C$ obtains its water from a tunnel whose intake is located near the intake of the canal above the Falls.

15. This was part of a plan of the original Niagara Falls Power Company to establish close to the Falls an industrial community consisting of heavy industrial users of electric and water power. The rapid advance in large scale generation of electricity made it impractical for plants to use water power. Actually, only International and the local water works leased water; the rest contracted for large amounts of electricity. The transactions by which International and its predecessors acquired their water rights are complicated. In 1891 it leased its plant site and water rights, and in 1896 it purchased the fee; the deed provided that International could divert water sufficient to generate 3000 h.p. upon payment of $\$ 24,000$ per year to Niagara. By a lease also made in 1896, and a supplemental agreement made in 1898, International received the right to divert additional water to develop up to 2900 h.p. at a fixed rental of $\$ 29,000$ per year, and still additional water at $\$ 10$ per h.p. per year. The 1898 agreement extended the outermost limits of the options contained in the 1896 lease from 1936 to such additional terms of 10 years each as International desired. It also guaranteed to International for this unlimited period the right to divert sufficient water to generate 4200 h.p. in addition to the 3000 h.p. given by the 1896 deed.

16. This company is the immediate predecessor of Niagara Mohawk as to the 1icense involved here. See note 11 supra. 
put on stand-by. ${ }^{17}$ This arrangement, thought to be the most efficient use of Niagara water, was urged as a defense measure by the Government. ${ }^{18}$ Included in this arrangement was an agreement by International to cease generating its own power and to buy electricity from Niagara. ${ }^{19}$ In return Niagara would pay annual rentals of $\$ 99,000$ a year for use of the water to which International was otherwise entitled. ${ }^{20}$

Pettebone-Cataract Water Rights:- The Pettebone-Cataract Companies ${ }^{21}$ were among the users of the canal basin's water. They drew 262.6 c.f.s. from the basin, ran it through their mills, and returned it over the bank to the river. ${ }^{22}$ In 1925 Niagara leased these water rights in a manner similar to the way it leased the International rights. ${ }^{23}$ The mills were torn down and in 1947 Niagara purchased the fee to these rights. ${ }^{24}$

17. The Adams Plant was not actually put on a stand-by basis until the 1930's. Today it is in full operation to utilize the emergency diversion of 12,500 c.f.s. permitted Niagara. See note 10 supra.

18. See 2 Adams, Niagara Power 257 (1927), which states that International's use of the water was inefficient. Adams' work is a long, detailed history of the use of Niagara water. It was published by the Niagara Falls Power Company, of which the author was a founder.

19. At this time (1919) International was developing 8156.2 h.p. (725 c.f.s.) for which it paid Niagara $\$ 74,562$. It had, however, under its deed and lease, the right to use a total of 730 c.f.s. Transcript of Record, p. 222, Niagara Mohawk Power Corp. v. FPC, supra note 1. The various deeds, leases, and agreements are all set forth in the record.

20. The rental provided by the lease was that International was to pay $\$ 20$ per e.h.p. (electrical horsepower per year) received from Niagara. But it was not to pay more than $\$ 76,000$ a year for the first 8750 e.h.p. used (as "firm power"). At $\$ 20$ per e.h.p. International saved $\$ 99,000$ a year on this firm power, which, when added to the $\$ 75,000$ it had been paying in water rentals, meant that it received about $\$ 175,000$ each year for its water rights in addition to whatever savings it made in not operating its own power generating equipment. In 1937 the New York Public Utilities Service Commission required Niagara to charge uniform industrial rates. The 1919 agreement was amended to provide for payment of $\$ 99,000$ a year in cash to International as the "fair and reasonable annual use or rental value of the water." Transcript of Record, pp. 243-4, Niagara Mohawk Power Corp. v. FPC, supra note 1.

21. The proper names of these companies are: Pettebone-Cataract Paper Company and Cataract City Milling Company.

22. Later, instead of being dropped directly into the river, this unused water was run through penstocks into Niagara's Schoellkopf Plant. Niagara's right to so collect and use this water was the subject of the litigation in Hydraulic Power Co. v. Pettebone-Cataract Paper Co., 198 App. Div. 644, 191 N.Y. Supp. 12 (4th Dep't 1921), affirming 112 Misc. 528, 183 N.Y. Supp. 373 (Sup. Ct. 1920).

23. The assets of Pettebone-Cataract were acquired by Niagara Lockport and Ontario Power Company in 1925. At the same time all of the assets except the water rights in issue were conveyed by Niagara Lockport to Niagara Falls Power Co. in satisfaction of a $\$ 172,000$ judgment held by the latter as a result of the litigation cited in note 22 supra. The water rights were rented to Niagara Falls Power Co. in return for cut rate power to be delivered to Niagara Lockport. To complicate the situation further, Niagara Lockport and Niagara Falls Power Co. were both controlled during all the relevant times by the same parent, Buffalo Niagara Electric Company, which in turn was consolidated into its parent Niagara Mohawk in 1950.

24. Since Niagara Lockport had been merged with Buffalo Electric in 1945, the latter was the seller to its subsidiary, Niagara Falls Power Company. The sale was approved by both the SEC (under the Holding Company Act powers) and the 
Niagara or its predecessors have always satisfied in their own names any necessary state or federal regulatory requirements covering use of the International and Pettebone-Cataract water rights. However, the claims of the latter companies to these water rights have long been a matter of public record. For instance, the FPC license under which Niagara operates its project states that in regard to recapture, or any other taking of the project by the United States or another licensee:

"Such taking over of the project shall also be subject to the rights, if any, of Pettebone-Cataract Paper Company and Cataract City Milling Company to withdraw water at a rate not exceeding 265 cubic feet per second from the hydraulic canal or basin of the licensee, and to the rights, if any, of International Paper Company." 25

Of course a principal problem of this case is to determine the significance of the words "if any."

\section{The Federal Water Power Act of 1920}

The Federal Water Power Act, which is now Part I of the Federal Power Act, was enacted in 1920 after many years of national and congressional debate. ${ }^{26}$ It provides for public and private development of water power primarily under federal supervision, ${ }^{27}$ but in some aspects there is ". . . careful preservation of separate interests of the States throughout the Act, without setting up a divided authority over any one subject." 28

New York Public Service Commission. See Niagara Mohawk Power Corp. v. FPC, supra note 1 , at 196 . The purchase price was $\$ 728,415.28$, which was stated to be the cost of the water rights to Niagara Lockport, who was also the first person to devote the property to public service. Thus there was no disallowance of the sales price, despite the affiliation between buyer and seller. Actually that sum was the exact amount paid for the Pettebone properties by Niagara Lockport in addition to assumption of the judgment. However, if Niagara Falls did not need to acquire the Pettebone rights to use the water (which is what the FPC contends) then it was not necessary for it to pay over $\$ 728,000$ for the fee for such rights, regardless of what Niagara Lockport paid for them. Yet the FPC has not disallowed this item from the project accounts; it has only disallowed the rentals paid until purchase of the fee.

25. Transcript of Record, p. 27, Niagara Mohawk Power Corp. v. FPC, supra note 1 (italics added).

26. United States ex rel. Chapman v. FPC, 345 U.S. 153, 167 (1953); First Iowa Hydro-Electric Coop. v. FPC, 328 U.S. 152 (1946); see KerwIN, FeDERAL Water Power Legrslation (1926) ; Pinchot, The Long Struggle for Effective Water Pozver Legislation, 14 Gro. WAsH. I. REv. 9 (1945). Compare Brown, The Conservation of Water Pozer, 26 HARv. L. REv. 601 (1913).

27. Secretary of the Interior Houston stated when the Bill was under consideration: “. . . [the bill] proposes a method by which the waterpower of the country $\therefore$ can be developed by public or private agencies under conditions which will give the necessary security to the capital invested and at the same time protect and preserve every legitimate public interest. ..." H.R. REP. No. 61, 66th Cong., 1st Sess. 5 (1919).

28. First Iowa Hydro-Electric Power Coop. v. FPC, 328 U.S. 152, 174 (1945). 
Although the Act recognizes state regulation to some extent, the ultimate responsibility for development and use of water power was consciously placed in the Federal Government and its agency the FPC. For instance, the FPC decides who may develop a water power site, and under what conditions, e.g., the size, type, and exact location of a project. Rates are to be regulated by the FPC in absence of state action in this field. ${ }^{29}$ Even if state regulation is in effect, the FPC may ultimately control the profits of licensed projects by reason of the fact that at the expiration of a license the FPC must determine whether or not earnings from the project have been excessive. $^{30}$ Finances and accounting are also subjected to detailed federal control..$^{31}$

As mentioned, under the Act the United States, or a subsequent licensee, may purchase or "recapture" a project at the end of the license $^{32}$ (usually fifty years). The price to be paid is the "net investment" of the licensee: the original cost of building the project or its fair value at the time of recapture, whichever is lower, less certain deductions.

Cost is the "actual legitimate original cost." 33 This is the famous "original cost," the cost to the person who first devoted the property to public service, ${ }^{34}$ and may be less than the actual cost to the licensee. It does not include profits paid to an affiliate on account of the project; for instance, if an affiliate built the project, any profit made by it would not be allowed as a "cost." This definition of cost does not generally include any amount paid by the licensee which is in excess of the project's cost of construction. This is true even if the purchase was made in an arm's length transaction with a non-affiliated company. Thus upon recapture no compensation will be paid for increase in value due to changes in the price level, sales of the project, or mere book write-ups. ${ }^{35}$ The Act also specifically excludes compensa-

29. Sections 19, 20, 16 U.S.C. $\$ \$ 812,813$ (1946).

30. Sections 3(13), 14, 15, 16 U.S.C. $\$ \$ 796(13), 807,808$ (1946).

31. Section 4(b), 16 U.S.C. $\$ 797$ (b) (1946); $\$ 301$ (b), 16 U.S.C. $\$ 825(b)$

(1946) (formerly $\$ 4(f)$, but placed in $\$ 301$ by amendment in 1935, 49 STAT. 839).

32. Section 14, 16 U.S.C. $\$ 807$ (1946).

33. Section 3(13), 16 U.S.C. \$796(13) (1946).

34. 18 Code FED. REGS. 101.3-3 (1949); Louisville Hydro-Electric Co., 13 FPC ANN. REP. 307, 314 (1933).

35. The interpretation announced by the Federal Power Commission of "actual legitimate original cost" as the cost to the person who first devoted the property to public service has been upheld both as constitutional and a proper construction of the Power Act. Pennsylvania Power \& Light Co. v. FPC, 139 F.2d 445 (3d Cir. 1943), cert. denied, 321 U.S. 638 (1946) ; Niagara Falls Power Co. v. FPC, 137 F.2d 787 (2d Cir.), cert. denied, 320 U.S. 792 (1943) ; Louisville Gas \& Electric Co. v. FPC, 129 F.2d 126 (6th Cir. 1942), cert. devied, 318 U.S. 761 (1943) ; Northern States Power Co. v. FPC, 118 F.2d 141 (7th Cir. 1941); cf. United States v. New York Telephone Co., 326 U.S. 638 (1946); Northwestern Electric Co. v. FPC, 321 U.S. 119 (1944); see Kripke, $A$ Case Study in the Relationship of Law and Acconnting: Uniform Accounts 100.5 and 107, 57 HARv. L. REv. 433, 693 (1944). 
tion for good will, going value, or prospective revenues. ${ }^{36}$ The final limitation on cost of the project, and one that is important to this case, is that contained in section 14 of the Act:

". . . nor shall the values allowed in net investment for water rights, rights-of-way, lands, or interest in lands be in excess of the actual reasonable cost thereof at the time of acquisition by the licensee." 37

The principal deduction made from "original cost" (or fair value) to determine "net investment" is the amount accumulated during the period of the license from "earnings in excess of a fair return on such [cost]." 38 Accordingly, if the consumers have been charged too much during the licensed period, the price paid by the United States is reduced by such excess, even if the rates collected were proper under state law..$^{39}$ Further, "earnings" are specially defined. That is,

36. Section 14, 16 U.S.C. $\$ 807$ (1946).

37. In the decision below (although not before the FPC, see note 43 infra) the parties and the court assumed that the definition of "net investment" is the same whenever used in administration of the Power Act, e.g., rate fixing, temporary taking, amortization reserves, and recapture. This seems correct, since it greatly facilitates uniform and simplified accounting throughout the life of a licensed project. But it should be noted that this requires reading the limitations on net investment contained in $\$ 14$ into $\S 3(13)$, which contains the primary definition of the term. Because $\$ 14$ applies to "values allowed" its limitations would apply, in determining earnings, both to determination of capital costs and to allowance of operating expenses. Perhaps "reading in" is too strong a characterization since, as discussed below, $\S 14$ 's limitations may be merely an amplification of redundant statement of $\$ 3(13)$ 's ceiling on allowable costs, that is, those which are "actual legitimate [and] original." See notes 162 and 164 infra. In that case it would be preferable, though perhaps inaccurate, to apply the limitation quoted in the text to determination of operating expenses and thus earnings (not just to determination of capital expenses) as seems to be the purpose of the limitation in $\$ 3(13)$. However, if none of the constructions indicated above to be preferable are upheld, then the issues discussed in this article may not be completely ripe for decision in Niagara Mohazek which, after all, involves only creation of amortization reserves and determination of what are operating expenses. Ripeness would await expiration of Niagara's license and recapture. $C f$. Metropolitan Edison Co. v. FPC, 169 F.2d 719, 724 (3d Cir. 1948). This would mean that in regard to allowance for water rights expenditures, although licensees would have to compensate those who own such rights under state law, it would be unclear what part of such expenditures would be allowed in computation of net investment in connection with matters such as rate making, temporary taking, and creation of amortization reserves. And, upon recapture, herculean and deft accounting efforts would be needed to reconcile the previous allowance with the amount that $\$ 14$ requires to be allowed in net investment upon recapture. This complexity results because $\$ 14$ 's limitation of allowance of values for water rights is their "actual reasonable cost," but it would apply only in the case of recapture. For all other purposes of the Act, the definition of net investment in $\$ 3(13)$ would be used, and it does not specially deal with allowance of expenditures for water rights. Such a jumble should be avoided if at all possible. Uniform accounting in respect to water rights can be accomplished by either of the two constructions suggested above which link $\$ \S 3(13)$ and 14. If either be adopted, net investment would carry the same signficance throughout the Act, wherever used in administration of a licensed project. Further, the question discussed in this article would be ripe for decision in Niagara Mohawk.

38. Section 3(13), 16 U.S.C. \$796(13) (1946).

39. Cf. Safe Harbor Water Power Corp. v. FPC, 179 F.2d 179, 187 (3d Cir. 1949), cert. denied, 339 U.S. 957 (1950). But the licensee gets no relief if the 
some of the amounts included in the licensee's rates for depreciation, exhaustion, or replacement of plant may be treated as earnings. ${ }^{40}$

The Act contains provisions to protect capital and prevent distribution of excess earnings as dividends prior to the end of the license. Section $10(d){ }^{41}$ requires that after the first twenty years of operation of the project, the licensee shall place in an "amortization reserve" a designated proportion (usually one half) of its subsequent "surplus earnings" 42 made after that date which are in excess of a certain rate of return on the net investment specified in the license (usually $6 \%$ ). ${ }^{43}$ This reserve is credited against the price to be paid upon recapture. This specified rate of return is not necessarily the same per cent as the "fair return," the size of which is determined at the expiration of the license."

\section{Regulation of Niagara by the Federal Government}

From 1900 until 1920 Niagara's predecessors used the water in question under the authority of temporary federal permits. These

earnings were inadequate during the license period; he merely receives the original cost or fair value of the project, whichever is lower. Puget Sound Power \& Light Co. v. FPC, 137 F.2d 701 (D.C. Cir. 1943).

40. Section $3(13)$ provides for the computation of net investment by deducting from the "actual legitimate original cost" of the project the following items: ". . . to the extent that such items have been accumulated during the period of the license from earnings in excess of a fair return on such investment: (a) Unappropriated surplus, (b) aggregate credit balances of current depreciation accounts, and (c) aggregate appropriations of surplus or income held in amortization, sinking fund, or similar reserves, or expended for additions or betterments or used for the purposes for which such reserves were created. . . " The exact significance of these provisions, covering the amounts in "current depreciation accounts" to be deducted from project costs, has not been settled. See Judge Biggs' excellent discus-sion in Safe Harbor Water Power Corp. v. FPC, supra note 39, at 193-8; Hearings before House Committee on Water Power, 65th Cong. 2d Sess. 38-9 (1918). But cf. Niagara Falls Power Co., 9 F.P.C. 228, 243-4 (1950).

41. Section 10 (d) provides in part: "That after the first twenty years of operation, out of surplus earned thereafter, if any, accumulated in excess of a specified reasonable rate of return upon the net investment of a licensee in any project... the licensee shall establish and maintain amortization reserves, which reserves shall, in the discretion of the Commission, be held until the termination of the license or be applied from time to time in reduction of the net investment. . :

42. This term is not specially defined by the Act or the regulations.

43. Before the commission, Niagara had argued that in computing net investment, excessive earnings made in the first twenty years of operation were not to be deducted from the cost of the project upon which future excessive earnings were to be computed. This was because before the 1935 amendment to the Power Act, $\S 10$ (d) used the words, "actual legitimate investment" instead of "net investment," as the base for measuring excessiveness. But the commission correctly noted that, according to its legislative history, the amendment was to insure that the standards of definition of net investment in $\$ 3(13)$ be used as the base for the amortization reserve; and that it probably could have been applied under the old language. See Louisville Gas \& Electric Co. v. FPC, 129 F.2d 126, 133 (6th Cir. 1942). See also Sen. Rep. No. 621, 74th Cong., Ist Sess. 45 (1935); H.R. ReP. No. 1318, 74th Cong., 1st Sess. 24 (1935).

44. See 1 FPC ANN. REP. 59 (1921). It should be noted that the licensee will be permitted to make up past deficiencies in earnings (below the rate specified in his license) before any earnings in excess of the specified rate are placed in the amortization reserve. See Niagara Falls Power Co., 9 F.P.C. 228, 256 (1950). 
permits all contained provisions which recognized that Niagara permitted the International Paper Company to use the water. ${ }^{45}$ The last annual permit contained a provision for immediate termination on the effective date of a Federal Water Power Act, if it became effective within the year. ${ }^{46}$ The Act went into effect before the year was up. In Niagara Falls Power Co. v. FPC, ${ }^{47}$ the Second Circuit held that Niagara's plants were subject to regulation and licensing just as any project built after the Act. It held that despite any rights it had under state law, as against the Federal Government in 1920 Niagara did not, have any vested right to use the waters in question. ${ }^{48}$

The FPC Decision:-Niagara, the first licensee of the FPC, was also the first ordered to create an amortization reserve under section 10 (d) of the Power Act. This reserve was ordered created as of March 1, 1941, twenty years after issuance of the FPC license. After hearings, the FPC ordered Niagara to place in the reserve one half of all its earnings in excess of six per cent made after March 1, 1941.49

The order went further. It disallowed as operating expenses rentals paid for the International and Pettebone water rights and directed that they be included in earnings made from March 2, 1941 through December 31, 1946. ${ }^{50}$ Presumably the same result

45. Permits covering the years 1900 to 1905 were obtained from the War Department pursuant to the Act of 1899, 30 STAT. 1121 (1899). They authorized placement of certain structures in the River, but not diversion of the water. From 1906 to 1913, permits for use of water were obtained under the Burton Law, 34 STAT. 626 (1906), and extensions thereof, 37 STat. 43 (1911), 37 STAт. 631 (1912). From 1917 to 1920 permission to use the water was given pursuant to congressional joint resolutions. 39 Stat. 867 (1912); 40 Stat. 241 (1917); 40 Stat. 633 (1918); 41 Stat. 163 (1919).

46. 41 StaT. 163 (1919).

47. 137 F.2d 787 (2d Cir.), cert. denied, 320 U.S. 792 (1943).

48. The court found that the temporary permit did not confer such a right since it expired the instant before the Act went into effect. Therefore Niagara had no vested right to maintain the project as against the United States; it would therefore be valued for recapture, or for determination of net investment, at "original cost." Cf. Wisconsin Pub. Serv. Corp. v. FPC, 147 F.2d 743, 748-9 (7th Cir. 1947). If it had a vested right, $\$ 23(\mathrm{a}), 16$ U.S.C. $\$ 816$ (1946) of the Act requires that the project be valued at its "fair value" as of the date the license was issued. In regard to water rights, this would have meant that since they were vested as against the United States, compensation would be required for their taking and allowance therefor made in net investment. The Power Act seems to provide for such compensation if the project is taken by the United States prior to expiration of the license; that is, licensing completely vests water rights of limited duration in the licensee. Section 14, 16 U.S.C. $\$ 807$ (1946) (proviso clause). Cf. Monongahela Navigation Co. v. United States, 148 U.S. 312, 336 (1893).

49. Niagara Falls Power Co., 9 F.P.C. 228 (1950).

50. The International and Pettebone water rights were the only ones outstanding in the Niagara area. The rights of other companies who had drawn water from the hydraulic canal had been acquired by Niagara prior to issuance of the license. See Niagara Falls Power Co., 9 F.P.C. 228, 252 (1950). See also note 158 infra. 
will follow (if the commission is upheld) for rentals paid after the latter date; and rentals paid prior to 1941 will also be included as earnings in the computation of any "excessive earnings" at the time of recapture..$^{51}$ That is, the result of this case will probably be conclusive as to all rentals for water rights paid over the fifty year period of the license. This amounts to about $\$ 5,780,000$ in this case. ${ }^{52}$

The rationale of the FPC decision was that the money spent for these rentals was uselessly expended. Nothing was obtained, because neither International nor Pettebone had anything to lease. The FPC stated that International and Pettebone do not

". . . possess a lawful title to the water rights in question for the reason that there cannot be private ownership of the waters of a navigable river of the United States.

"It is . . . futile for [a] licensee to lease and pay rental for rights it already owns under its license. On that basis the staff adjustment rests." 53

The Court of Appeals Decision:-On appeal from the FPC order the Court of Appeals for the District of Columbia, per curiam, reversed, Judge Bazelon dissenting. ${ }^{54}$

51. These questions were of course not before the Commission for decision, but they involve the identical issues of law and fact as the instant case.

52. This is computed on the basis of a rental of $\$ 99,000$ a year for 50 years (the license period) in regard to the International water rights, and $\$ 37,800$ a year for 22 years (1925-1947) for the Pettebone rights.

53. Niagara Falls Power Co., 9 F.P.C. 228, 252 (1950). The FPC was quoting from its decision in Niagara Falls Power Co., 6 F.P.C. 184, 186 (1947). This was an application by Niagara, after its purchase of the fee to the Pettebone rights, to have the clause in the license mentioning these rights deleted, that is, to make these rights subject to the license. This clause is quoted in the text at note 25 supra. The FPC stated that it regarded the words as meaningless because Niagara's rights to the water stemmed solely from its federal license. However, it refused to grant the amendment because it thought such action might recognize the necessity for Niagara to acquire the Pettebone rights. Niagara Falls Power Co., 6 F.P.C. 184, 188 (1947). An exchange of correspondence revealed that the FPC considered this action determinative of the issue involved in the instant case, and consequently in its opinion and before the court of appeals it contended that the denial of the amendment was res judicata as to the unnecessary nature of Niagara's expenditure for state created water rights. Niagara Falls Power Corp., 9 F.P.C. 228, 251-2; Niagara Mohawk Power Corp. v. FPC supra note 1, at 197. The court below rejected this contention, and the ruling seems proper. Doctrines such as collateral estoppel are reluctantly applied in regard to administrative agencies. Churchill Tabernacle v. FCC, 160 F.2d 244, 246 (D.C. Cir. 1947). It is also doubtful that the FPC action denying the amendment was appealable as a final order, for it lacked substantive effect. Section 6, 16 U.S.C. $\$ 799$ (1946), of the Power Act provides that licenses may be altered only "upon mutual agreement between the licensee and the Commission," which indicates that granting of the amendment was purely a discretionary matter. The action of the FPC merely left the license where it was, a state of affairs to which Niagara consented when it received the permito

54. Niagara Mohawk Power Corp. v. FPC, supra note 1. The majority consisted of Judges Kimbrough Stone and Wilbur K. Miller. 
The majority held that the International and Pettebone water rights were valid "usufructuary rights," interests in real property which could be leased to Niagara under New York law. Although these rights were, and are, always subject to the servitude of the Federal Government for purposes related to navigation, they were not destroyed, either by the Treaty of 1910 or by the Power Act. A licensee may not proceed to use the water just because he has a federal license; it must comply with state property law in regard to use of water.

"The Act is purely a regulatory measure. A federal license is not an original grant of authority, but a permission to use a state's grant of authority." 55

But the court went on to recognize that a federal license, as well as rights under state (property) law, was needed to divert navigable waters. $^{56}$ In reaching its conclusions, the court relied on section 27 of the Act, which provides:

"Nothing contained in this chapter shall be construed as affecting . . . the laws of the respective States relating to the control, appropriation, use, or distribution of water used in irrigation or for municipal or other uses, or any vested right acquired therein."

The court stated:

". . The language of Sec. 27 is clear and unequivocal . . . Congress did not intend the Water Power Act to destroy vested property rights such as those here involved, but only to regulate their exercise." 57

Accordingly, the majority held that since Niagara was required by state law to compensate for its use of the International and Pettebone water rights, the leases in question were valid, and rentals paid thereunder were to be allowed as operating expenses and not to be included in earnings. In effect, this means that upon recapture the United States must reimburse Niagara for these rentals.

55. Niagara Mohawk Power Corp. v. FPC, supra note 1 , at 207.

56. Ibid. "To be sure, a license is a pre-requisite in that water rights under state law in a navigable stream may not be exercised without one. . ."

57. Id. at 205. The court also relied on other sections of the Act which mention water rights, for instance $\S 14$, which states that values allowed for "water rights" in determining the net investment shall be limited to the "actual reasonable cost;" $\$ 3(11)$, which includes "all water rights" in the definition of the licensed project property; $\$ 4(\mathrm{~b})$, which includes "water rights" as one of the items whose cost the licensee must report to the commission; and $\$ 9(\mathrm{~b})$, which requires an applicant for a license to show that he has complied with state law with respect to the "bed and banks and to the appropriation, diversion and use of water for power purposes." 
In dissenting, Judge Bazelon asserted:

". . . At least as applied to the United States or its licensee as such, the Federal Power Act is an assertion of the commerce power which constitutes a taking by the United States without compensation of all water rights affecting navigable streams except to the extent and in the manner that the Act expressly saves certain rights created under state law." 58

Contrary to the majority, he interpreted section 27 as not preserving the water rights in question; it saves only water rights related to irrigation or municipal uses. Therefore when section 14 refers to compensation for water rights upon recapture, it does not save the instant rights, for they are not related to irrigation or municipal uses. $^{59} \mathrm{He}$ concluded that the water rights in question were taken by the Act, and therefore no compensation would be paid for them on recapture. The federal license was all that Niagara needed to use the water.

In general, the position of this article is that expenditures by Niagara for water rights should be disallowed only to the extent that they are unreasonable in amount. But, before developing this thesis it will help to summarize the settled law dealing with the interest of the Federal Government in navigable waters.

\section{The Constitutional Seting of the Problem}

Since Gibbons v. Ogden, ${ }^{60}$ the commerce clause has been held to give the Federal Government, or its instrumentality, power over navigable waters. It has a servitude to use or regulate use of such waters, including use of water to generate electricity. ${ }^{01}$ It need not compensate riparian owners whose utilization of the water is affected by such federal use or regulation. ${ }^{62}$ However, owners must be compensated for fast land (above the mean high water mark) taken or affected, e.g., flooded. ${ }^{63}$ But the price to be paid for such a taking need not include compensation for the value of the land as a water power site. ${ }^{04}$ Thus were the Federal Government itself to develop

58. $I d$. at 209.

59. As for the other sections of the Act, cited by the majority as saving, or mentioning, water rights, Judge Bazelon asserted that they relate only to filing information with the commission and do not have the substantive effect of preserving state created interests in water.

60. 9 Wheat. 1 (U.S. 1824).

61. United States v. Willow River Power Co., 324 U.S. 499, 509 (1945).

62. United States v. Chicago, M., St. P., \& P.R.R., 312 U.S. 592 (1941) ; United States v. Chandler-Dunbar Water Power Co., 229 U.S. 53, 65 (1913).

63. See United States v. Willow River Power Co., 324 U.S. 499, 509 (1945).

64. Washington Water Power Co. v. United States, 135 F.2d 541 (9th Cir.), affirming 41 F. Supp. 119 (E.D. Wash. 1941), cert. denied, 320 U.S. 747 (1943). 
water power such as that at Niagara, it would, in a condemnation proceeding, ". . . have to pay the fair value, judicially determined, for the fast land; nothing for the water power." ${ }^{65}$ As against the Federal Government's navigation servitudes, there are no private property rights in the flow of a navigable stream. But unless and until the Federal Government has exercised this servitude by using the water power or prohibiting its use by others, in order to use water power of a navigable stream a person need only fulfill the requirements of state law. ${ }^{66}$ Further, when it does exescise this servitude, the Federal Government may provide for limited or complete preservation of state created interests in the water power or lands affected. ${ }^{.7}$

In United States v. Chandler-Dunbar Water Power Co., ${ }^{68}$ Congress had directed the condemnation of certain lands in order to improve navigation on the St. Mary's River. Water power produced by these improvements was to be used to generate electricity. Compensation was sought for the value of water rights and for the value as a power site of fast land on the banks of the river. Denying these claims, the Supreme Court held:

"This title of the owner of fast land upon the shore of a navigable river to the bed of the river . . . is subordinate to the public right of navigation, and . . . is of no avail against the exercise of the great and absolute power of Congress over the improvement of navigable rivers. . . ." 69

65. United States v. Appalachian Electric Power Co., 311 U.S. 377, 427 (1940). See United States v. Kansas City Life Ins. Co., 339 U.S. 799, 805n. (1950); Note, Federal Development of State Resources in 1 FreUnd, SUTHERLAND, Howe aNd Brown, Constirutronal Law 307 (Temp. ed. 1952). However, if federal action in regard to a navigable stream affects the water rights of a riparian owner on a non-navigable tributary, he is apparently entitled to compensation for loss of property. United States v. Cress, 243 U.S. 316 (1917). Yet \$23, 16 U.S.C. \$817 (1946), of the Power Act provides that under the commerce power such an owner's use of non-navigable water requires an FPC license and submission to its attendant regulations. See Grand River Dam Authority, CCH FED. UTrL. LAW REP. ITT 10,753, 10,757 (1953). 418 (1926).

66. See, e.g., United States v. River Rouge Improvement Co., 269 U.S. 411,

67. Cf. United States v. Gerlach Live Stock Co., 339 U.S. 725, 734-42 (1950) (construing the Reclamation Act, 43 U.S.C. $\$ 371$ et seq.).

68. 229 U.S. 53 (1913). This was the only case cited by the FPC opinion in support of its decision on the water rights here in issue. It is hardly on all fours since it involved a project to be built by the United States; the Power Act only involves federal regulation.

69. $I d$. at 62 . The Court continued: ". . that the running water in a great navigable stream is capable of private ownership is inconceivable.

“...

“. . . The Government had dominion over the water power of the rapids and falls and cannot be required to pay any hypothetical additional value to a riparian owner who had no right to appropriate the current to his own commercial use. These additional values represent, therefore, no actual loss and there would be no justice in paying for a loss suffered by no one in fact. . . ." Id. at 69, 76. 
Subsequent cases have reached an identical result. ${ }^{70}$ It is also well established that the United States need not compensate for water rights even though it uses or leases the water power to generate electricity for sale. ${ }^{71}$ The Government need only show that the power generation is part of a project connected with navigation. ${ }^{72}$

Insofar as regulation of private water power projects are concerned, similar conclusions have been stated by the Court. For instance, in upholding the constitutionality of the Federal Power Act itself Justice Reed said:

". . . In our view, it cannot properly be said that the constitutional power of the United States over its [navigable] waters is limited to control for navigation . . . the respondent cannot, by seeking to use a navigable waterway for power generation alone, avoid the authority of the Government over the stream. That authority is as broad as the needs of commerce. Water power development from dams in navigable streams is from the public's standpoint a by-product of the general use of the rivers for commerce." " 3

Enactment of the Power Act partially exercised this broad federal servitude over navigable waters. It is firmly settled that the Act makes it necessary to comply with federal regulation, and to obtain a federal license, in order to use the water power of navigable streams. This requirement exists regardless of the fact that the prospective user has fulfilled all the requirements of state property and regulatory law in respect to such use. ${ }^{74}$ In addition, any conflicting state regulation of navigable waters must give way to FPC action. For instance, a licensee may build a dam in a location approved by the FPC even though he is forbidden to do so by the law or regulatory authorities of the state. ${ }^{75}$

What has not been decided is the question presented by this case: what state property rights in water power are destroyed or limited by the Power Act or the grant of a license thereunder? Three possibilities present themselves: (1) A licensee under the Power Act

70. See notes 61 through 65 supra.

71. The power generated by the surplus water is held to be government property the disposition of which is within the absolute discretion of Congress. United States v. Chandler-Dunbar Water Power Co., 229 U.S. 53, 73 (1913). This is true even if navigation is but an incident of a project, and its main purpose is power generation. Ashwander v. TVA, 297 U.S. 288, 335 (1936).

72. For a discussion of the requisite connection with navigation, see United States v. Gerlach Live Stock Co., 339 U.S. 725, 737 (1950); Arizona v. California, 283 U.S. 423, 455-8 (1931).

73. United States v. Appalachian Electric Power Co., 311 U.S. 377, 426 (1940).

74. E.g., United States v. Appalachian Electric Power Co., 311 U.S. 377, 423 (1940) ; Niagara Falls Power Co. v. FPC, 137 F.2d 787, 791 (2d Cir. 1943).

75. First Iowa Hydro-Electric Coop. v. FPC, 328 U.S. 152, 164 (1946). 
need not acquire the property rights to water power required by state law any more than it must comply with state regulatory directives as to where it may build its dam. (This is the position of the FPC.) (2) A licensee must acquire such state created property rights; the Power Act merely imposed an additional requirement that federal regulation and licensing provisions also be satisfied before navigable water is used. (This is the position of Niagara and the court of appeals.) (3) The Act limited the types of state property interests in water that need to be acquired by a licensee. It must obtain only the right to use the water power for the licensed period. That is, the issuance of a license destroys state property rights in the water that would otherwise exist at the end of the licensed period. (This is the position taken by this article.)

The Status of the International and Pettebone Rights UNDER NEW YoRK LAW

In the court of appeals, the FPC contended that the International and Pettebone interests in water were not recognized as property by state law. The majority specifically decided otherwise. Judge Bazelon in his dissent assumed this aspect of the majority decision to be correct. In its petition for certiorari the FPC does not claim this ruling to be erroneous, but in its brief the FPC in effect again raises this issue. There may be some doubt as to the analysis of New York law by the court of appeals. Determination of the status under New York law of the water rights in question requires analysis of these water rights in three respects: as against another private person who seeks to divert the water; as against whatever interest New York has in the water in its proprietary capacity; and as against New York in its sovereign capacity seeking to regulate the use of the water, including imposition of charges therefor.

Private Persons:-There seems to be little question under New York law that both the International and Pettebone rights are superior as against interference by a stranger, e.g., a private person who seeks to divert the river upstream from the International Paper Plant. A full statement of New York law in this situation is found in a case defining the water rights of the old Hydraulic Canal Company, a predecessor of Niagara. There, the company had insisted that its right to divert water from the Niagara River was only a franchise from the state and therefore could not be taxed as real estate. The court held otherwise:

". . The relator, as a riparian owner and as owner of the land under the waters of the Niagara River adjacent to its 
uplands from which the water is immediately taken, has the right to the use of the waters of the river for manufacturing purposes, and to divert the same for that purpose, returning them to the river, as it does, after passing over its own lands [citations omitted], subject only to the paramount right of the State to utilize these waters for a public use, without compensation to such riparian owners; all riparian rights remaining unimpaired until the exercise of such paramount right by the State . . . the relator, as riparian owner, had the right to take waters from the Niagara River for manufacturing purposes, not interfering thereby with the navigability of the stream, such right being in no sense in the nature of a franchise but a corporeal hereditament, not depending either upon grant or prescription." 78

In later litigation, New York courts have specifically stated that the Pettebone rights were private property:

". . The defendants [Pettebone-Cataract Company]... are . . . owners of certain water rights, by virtue of which they take and have for years taken quantities of water from such [canal] basin and conducted the same to turbines upon their properties and thereby generated electrical power for their own private uses." 77

The Supreme Court of the United States has held the International water rights to be property under the law of New York in International Paper Co. v. United States. ${ }^{78}$ This case arose because in 1917 the United States requisitioned all the electric power that could be produced by Niagara under its permit from the Secretary of War. Since the requisition required Niagara, not International, to use this water, the latter's plant was forced to shut down and International sought damages therefor. The claim was allowed by a divided (6-3) Supreme Court, which reversed the judgment below. Held, Justice Holmes, for the Court:

". . . the Government took the property that petitioner owned as fully as the Power Company owned the residue of the water in the canal. Our conclusion . . . is that the Government intended to take and did take the use of all the water power in

76. People ex rel. Niagara Falls Hydraulic Power and Mfg. Co. v. Smith, 70 App. Div. 543, 546, 75 N.Y. Supp. 1100, 1101 (4th Dep't 1902). New York Real Property Law $\$ 2$ specifically defines real estate so as to include a corporeal hereditament. See also Van Etten v. City of New York, 226 N.Y. 483, 486, 124 N.E. 201, 202 (1919) ; United Paper Board Co. v. Iroquois Pulp and Paper Co., 226 N.Y. 38, 46-7, 123 N.E. 200,202 (1919).

77. Hydraulic Power Co. of Niagara Falls v. Pettebone-Cataract Paper Co., 198 App. Div. 644, 646, 191 N.Y. Supp. 12, 13 (4th Dep't 1921). Niagara brought this action to establish its right to utilize the balance of the water power head that remained after it ran throughout the Pettebone mill.

78. 282 U.S. 399 (1931). 
the canal; that it relied upon and exercised its power of eminent domain to that end; that, purporting to act under that power and no other, it promised to pay the owners of that power. . . " 79

As a cautionary note, it is in order to observe that this case does not decide the present one. Although it squarely holds that as of 1917-18 International had rights in the Niagara water which were recognized by state law, it is not a holding that the Government must pay if it appropriates these rights by exercise of the navigation power, which power is the authority for the Power Act.

State Proprietary Interest:-The first way in which the state might claim a proprietary interest is as a downstream riparian landowner. In 1884 the state acquired the land surrounding the Falls themselves. ${ }^{80}$ Accordingly, Niagara's upstream diversion of water reduces the volume flowing over the Falls and impairs New York's riparian rights. New York has a second source of proprietary interest. Under New York law the state in its proprietary capacity apparently has the right to use both the flow of the Niagara River and its bed without compensation and without regard to who owns the riparian land. ${ }^{81}$ However, these rights may be conveyed by the state ${ }^{82}$ or lost by prescription, ${ }^{83}$ subject to a shadowy limitation that the public trust must not be violated. ${ }^{84}$

Insofar as the instant water rights are concerned, Niagara has apparently obtained the necessary property rights from the State. ${ }^{85}$ They are derived not only through the chain of title to Niagara's

79. Id. at 408 (Justices McReynolds, Stone, and Roberts dissented).

80. Matter of Commissioners at State Reservation at Niagara, 37 Fun 537 (N.Y. 1885), appeal dismissed, 102 N.Y. 734, 7 N.E. 916 (1886). Early in the nineteenth century all the riparian land had been sold to private parties by the state.

81. Ibid. See People v. System Properties, 281 App. Div. 433, 440, 120 N.Y.S.2d 269, 279 (3d Dep't 1953). In the instant case the court of appeals was silent on this aspect of New York law. It cited a number of cases which dealt only with non-tidal streams in which New York has no proprietary right, e.g., Waterford Electric Light, Heat \& Power Co. v. State, 208 App. Div. 273, 203 N.Y. Supp. 858 (3d Dep't 1924), aff'd, 239 N.Y. 629, 147 N.E. 225 (1925).

82. First Construction Co. v. State, 221 N.Y. 295, 116 N.E. 1020 (1917) ; Williams v. The Mayor, 105 N.Y. 419, 11 N.E. 829 (1887); Langdon v. The Mayor, 93 N.Y. 129 (1883). See Long Sault Development Co. v. Kennedy, 212 N.Y. 1, 8, 105 N.E. 849, 851 (1914), appeal dismissed, 242 U.S. 272 (1916).

83. Matter of Commissioners at State Reservation at Niagara, 73 Hun 537 (N.Y. 1885).

84. Long Sault Development Co. v. Kennedy, 212 N.Y. 1, 8, 105 N.E. 849, 852 (1914) ; Niagara Falls Power Co. v. Duryea, 185 Misc. 696,57 N.Y.S.2d 777 (Sup. Ct. 1945$)$.

85. That Niagara, not the Pettebone and International Companies, obtained these rights is of no matter. In fact it may well have been Niagara's obligation to take such action, since it originally leased the water rights to International and Pettebone. What Niagara has been paying for is the surrender by these companies of their rights under their lease or conveyance from Niagara. 
real property (including the water rights), but also by virtue of a number of statutes authorizing its use of water. ${ }^{86}$ This conclusion is illustrated by the company's litigation with the State Water Power and Control Commission. In 1942 the commission attempted to impose upon Niagara's use of the water a statutory "equitable rental" from which "lawfully and previously acquired" rights were exempt.87 In enjoining the commission, the New York Court of Appeals held Niagara's use, and by implication the International and Pettebone rights, to be within the exemption. ${ }^{88}$

State Regulation:-In the last mentioned case, the New York Court of Appeals qualified its opinion:

“. . We make no determination as to the particular nature and extent of the defendant's rights or privileges as acquired from the State or as riparian owner, or as to the effect thereon of the state's reserved right to control or regulate or license, through appropriate legislation, the diversion of water from the Niagara River." 89

Accordingly, the very next year the Conservation Law was amended to eliminate the exemption from equitable rentals of rights "lawfully and previously acquired." 90 Upon signing the bill Governor Dewey stated, "This bill will bring to the State for the first time a reasonable compensation for use of the water now being diverted from the Niagara River." 01 Niagara promptly sought to enjoin imposition of rent under this statute. Mr. Justice Bergan, sitting at Special Term, decided for the state. ${ }^{22}$ He held that the rental was a proper

86. Statutes Authorizing Diversion for the Hydraulic Canal: N.Y. Laws 1886, c. 83 ; N.Y. Laws 1889 , c. 109 ; N.Y. Laws 1896 , c. 968 . Statutes Authorizing Diversion for the (Original) Niagara Falls Power Co.: N.Y. Laws 1891, c. $253 ;$ N.Y. Laws 1893, c. 477 . Statute Authorizing Consolidation of Local Companies into Niagara Falls Power Co. and Diversion of Water by it: N.Y. Laws 1918, c. 596, 597.

87. N.Y. Conservation Law, §634 (1928).

88. Water Power and Control Commission v. Niagara Falls Power Co., 289 N.Y. 353, 356, 45 N.E.2d 907, 908 (1942). This case actually covered only 15,100 c.f.s. of the 20,000 c.f.s. diverted by Niagara. In an earlier decision, it was held that the 1918 statute, supra note 86, permitting the consolidation which formed the Niagara Falls Power Company, was conditioned upon that company's agreement to pay a rental on the balance of 4,900 c.f.s. of water diverted by it. Niagara Falls Power Co. v. Water Power and Control Commission, 267 N.Y. 265, 196 N.E. 51 (1935).

89. Water Power \& Control Commission v. Niagara Falls, supra note 88, at 356. Contrary to the quoted words the court did determine that Niagara had some rights against the state which would appear to be of a proprietary nature.

90. N.Y. Laws 1943 , c. 46.

91. The Governor's remarks are reprinted in 10 McKinneY's Consolidated Laws of New York ANNOTATEd 456.

92. Niagara Falls Power Co. v. Duryea, 185 Misc. 696, 57 N.Y.S.2d 777 (Sup. Ct. 1945). 
exercise of the "reserve" or "paramount" powers of the state which existed over this natural resource. ${ }^{93}$ His decision was not appealed. ${ }^{94}$

The decision seems correct, for if the state in its sovereign capacity could prohibit use of the water, or use the water itself to generate power, all without compensation, then imposition of a rental seems justified as a milder exercise of sovereign power. But Justice Bergan did not even imply that imposition of this rental absolved Niagara, a private party, from respecting or paying for other private rights in water used by its project. That is, payment of the state's charge is an additional requirement to be complied with by the company, just as it must pay corporation and real estate taxes. ${ }^{95}$

The FPC's position in the circuit court was that the International and Pettebone rents, at least since the 1943 amendment to the Conservation Law, were paid to persons who had no interest in the water under New York law. The state alone should have been paid for it was the sole proprietor. Yet, the commission's own decision in the instant case contradicts this contention. For the commission allowed as operating expense Niagara's payment of $\$ 1,750,000$ in "equitable rentals" to the state. ${ }^{96}$ Yet if these charges were imposed by the state in its proprietary capacity, they should have been disallowed if the FPC is correct that the Power Act destroyed state created property rights. Assuming that its allowance of the rents was deliberate, the commission must have determined that New York law imposes the equitable rental as a regulatory measure and further that

93. There is general language in the opinion about the state taking, or taking back property rights. However, the decision seems to rest most firmly upon the exercise of regulatory or sovereign power. This analysis is fortified by the fact that there was no discussion of cases requiring compensation for water rights which the state, having previously conveyed in a proprietary capacity, later seeks to appropriate for a "non-public purpose." See note 82 supra. Further, there has been no direct repeal of any of the laws (listed in note 86 supra) permitting Niagara to divert water.

94. The majority in the instant case said that this unappealed decision represented ". . not destruction, but confirmation of private rights." 202 F.2d 190, 201 (D.C. Cir. 1952). This characterization is a bit strong. But although the New York case fails to explicitly confirm the instant water rights, it does not purport to destroy them.

95. Cf. Susquehanna Power Co. v. State Tax Comm'n. (No. 1 and 2), 283 U.S. 291,297 (1931). Of course it is true that the state's charge could be very high, as the Justice observed; yet as he noted the state has in the past treated the company fairly. Niagara Falls Power Co. v. Duryea, 185 Misc. 696, 706, 57 N.Y.S.2d 777, 786 (1945). At any rate, pessimism as to the amount of "equitable rent" does not destroy either the existence, or present value of water rights-"The fact that the State might destroy relator's riparian rights does not convert such right into a mere franchise. Interference with the relator's rights by the State is a contingency too remote to require serious consideration." People ex rel. Niagara Falls Hydraulic Power and Mfg. Co. v. Smith, 70 App. Div. 543, 546, 75 N.Y. Supp. 1100,1102 (4th Dep't 1902). See also United States v. River Rouge Improvement Co., 269 U.S. 411, 420 (1926).

96. Niagara Falls Power Co., 9 F.P.C. 228, 250, 261 (1950). Commissioner Smith, who concurred, noted this inconsistency. 
this charge does not conflict with the Power Act. The corollary of this result is that unless destroyed by the Federal Power Act, under New York law, private rights in water still exist and consequently had to be acquired by Niagara.

\section{The Liability of Licensees Under the Power Act for State Created Interests in Water}

We pass to the question of whether the Act requires a licensee to acquire such state created interests, regardless of whether payments therefor are to be allowed in his "net investment." Only if the Act imposes such a requirement do we reach the determination of what sums spent by a licensee for such interests will be allowed in computing net investment.

As discussed above, the FPC, and Judge Bazelon in his dissent, contend that the Power Act destroyed private interests in water other than those related to irrigation or municipal uses. Therefore they would completely disallow expenditures made by Niagara for such (extinguished) water rights as the International and Pettebone interests. However, the majority held that the Act did not affect the existing state created interests and, without discussion, assumed that the United States must allow any sums spent by the licensee in an arm's length transaction to acquire them. The position of this article is that to the extent that a licensee's expenditures therefor are to be allowed in computation of net investment these state created interests survive the Act and licenses issued thereunder.

The legislative history that there is, negatives any Congressional intent to completely destroy state created interests in water. An oft-quoted spokesman for the Bill, ${ }^{97}$ Representative LaFollette, stated at the outset of debate in the House of Representatives:

". . . [we] are definitely insisting that the State's rules of property as to water, bed and banks must have been fully complied with or license can not issue. . . ." 98

On the other hand, it is true that section 27 which the majority relied upon as saving the water rights here in issue, was apparently

97. Actually a number of bills for federal control of water power were introduced and hearings held thereon in the sessions of Congress preceding the 66th Congress, Second Session, when a conference bill was accepted and enacted into law. Since the bills, especially that of the House, considered in the 65 th Congress were very similar to the one actually passed, Congressional statements in regard to them have been given weight by the courts. See, e.g., First Iowa Hydro-Electric Coop. v. FPC, 328 U.S. 152 (1946). For a definitive history of the Congressional debates and hearings, see, KERWIN, op. cit. supra note 26.

98. 56 Cong. REc. 9110 (1918). He was to be sure referring in this excerpt to $\$ 9(\mathrm{~b})$ which, in First Iowa, was held not to prevent issuance of a license to an applicant who had not complied with state regulatory law. See text at note 111 et seq. infra. 
placed in the Act at the insistence of Representative Taylor who stated that he sought to insure that the FPC would not have jurisdiction over diversion of water for irrigation purposes. ${ }^{99} \mathrm{He}$ does not appear to have been interested in saving riparian rights such as existed at Niagara Falls; and other Congressional statements make it clear that diversions at Niagara Falls pursuant to such rights were to be subject to FPC regulation. ${ }^{100}$

But as to what state created interests in water must be acquired by a licensee, we need not "extrapolate meaning from surmises and speculation and free-wheeling utterances," or engage in "psychoanalysis of Congress." 101 A number of cases decided under the

99. 56 Cong. Rec. 9912, et seq. (1918). See also, Rep. Mondell's remarks, 56 Cong. REc. 9115 (1918). The amendment sponsored by Rep. Taylor was taken from the Reclamation Act of 1902, but there are significant differences between the two. See note 171 infra. It is also true that the Act covers any project which gathers water for use in irrigation if it also involved any power production. See Rep. Mondell's reluctant admission, ibid. $C f$. Harris v. Central Neb. Pub. Power \& Irrig. Dist., 29 F. Supp. 425, 429 (D. Neb. 1938).

Prior to Taylor's amendment, which was placed in the bill by the House Committee, the bill had been devoid of any special words saving private rights in water. See, Hearings Before House Committee on Water Power, 65th Cong., 2d Sess. 474-5, 619-23, 640-2 (1918). The bill, as it passed the Senate is found in 56 CoNG. REc. 225-7 (1917); the Senate Committee declared that it saved private water rights, but did not say how. SEN. REP. No. 179, 65th Cong., 2d Sess. 4 (1917). The version submitted to the House by the President's Committee is found in H.R. REp. No. 715, 65th Cong., 2d Sess. 21 et seq. (1918). The House Committee took this latter draft and wrote a compromise bill which is the most proximate ancestor of the Power Act. As noted, it contained the present $\$ 27,16$ U.S.C. $\$ 821$ (1946), but the Committee report offers only a paraphrase of it in explanation, H.R. REP. No. 715, 65th Cong., 2d Sess. 21 (1918). Section 27, 16 U.S.C. \$821 (1946), was subsequently incorporated in the bills passed by both the House and Senate in the 66th Congress, but the Committee reports again only paraphrased its language in explanation. H.R. Rep. No. 61, 66th Cong., 1st Sess. 11 (1919).

100. KERWIN, op. cit. supra note 26 , at 245-8. Originally the Niagara and all other International Boundary Waters were excluded from the Power Act and placed under the jurisdiction of the Foreign Affairs Committee. H. REs. 229, 65th Cong., 2d Sess.; 56 CoNG. REC. 844; Hearings, supra note 99, at 557 et seq. In the 66th Congress, boundary waters were not so excluded. Further, Senator Wadsworth obtained an amendment to $\S 23$ (a) of the bill to insure that diversion of water at Niagara Falls would be subject to FPC regulation. 59 CoNG. REC. 1482 (1920). The amendment does not purport to take away any state-created property rights; it provides that the Act "shall not be construed . . as confirming or otherwise affecting any claim [to water]..." The Senate had inserted another amendment which would have prevented the FPC from altering any contract for "power, light, heat or water to be furnished from any project works." (Italics added). Its principal purpose apparently was to prevent alteration of contracts by which Niagara sold a disproportionate amount of the cheap electricity available at the Falls to a few industrial customers. 59 Cong. Rec. 1440, 1490-1 (1920). The amendment was rejected by the Conference Committee. H.R. REp. No. 910, 66th Cong., 2d Sess. 12 (1920). The Committee, stated that the FPC should be able to exercise the traditional power of a public service commission, to alter rate contracts which are not in the public interest. There was no concern with the International and Pettebone cases of contracts for delivery of water to a project. And it seems unduly conceptual to say that by virtue of the series of transactions described in note 15 supra, Niagara first obtained the water, then delivered it to International under its deed and lease, and then received it back under the lease here in issue.

101. These characterizations, those of Justices Frankfurter and Jackson respectively, are found in their concurring opinions in the recent case of United States v. Public Utilities Comm'n, 345 U.S. 295, 321, 319 (1953). That case involved 
Power Act hold that a licensee must compensate owners of any state created interests in water that are affected by his project, not just those related to irrigation or municipal uses. Strangely, none of these cases were cited by the majority in the instant decision and only some of them were cited by the parties.

The first and leading case is Henry Ford and Son v. Little Falls Fibre $C_{0 .}{ }^{102}$ There, operation of the licensee's project on the Hudson River raised the water level of the Mohawk, a navigable tributary about plaintiff's dam. This increased level diminished the head (or fall) of water which furnished the power for the plaintiff's mill located on the Mohawk. ${ }^{103}$ In the New York courts the mill owner obtained a judgment for damages and an injunction against future operations decreasing the head. This judgment was unanimously upheld by the Supreme Court of the United States. The then Justice Stone held:

“. . . even though the rights which the respondents here assert be deemed subordinate to the power of the national government to control navigation the present legislation [the Power Act] does not purport to authorize a licensee of the Commission to impair such rights recognized by state law without compensation." 104

This conclusion was reached by reliance on sections 10 (c) and 27 of the Act. ${ }^{105}$ Section 10 (c) provides that licensees:

". . . shall be liable for all damages occasioned to the property of others by the construction, maintenance, or operation of the project works . . . constructed under the license and in no event shall the United States be liable therefor." ${ }^{106}$

the construction of $\$ 20$ of the Power Act, 16 U.S.C. $\$ 813$ (1946). The concurring Justices felt that the Court reached its decision via an over-broad definition of what is to be included within "legislative history."

102. 280 U.S. 369 (1930).

103. The increase in the level of the Mohawk apparently resulted from the licensee's placing flashboards atop a dam owned by the United States. Although it was authorized to do so by its FPC license, this authority does not clearly appear in the summary of the license in 1 FPC ANN. REP. 195 (1921); similar confusion is found in Buchanan v. United States, $78 \mathrm{Ct}$. Cl. 791, 793-94 (1934). However, use of the boards was specifically requested in the license application, and granted by the FPC license after approval by the Army Engineers as required by $\S 18$ of the Power Act, 16 U.S.C. \$811 (1946). See Little Falls Fibre Co. v. Ford \& Sons Inc., 127 Misc. 834, 837, 217 N.Y. Supp. 534, 538 (Sup. Ct. 1926), aff'd, 223 App. Div. 559, 560, 229 N.Y. Supp. 445, 448 (2d Dep't), aff'd, 249 N.Y. 495, 498-99, 164 N.E. 558, 560 (1928); Transcript of Record, pp. 22-29, 237, 244-45, Henry Ford \& Son v. Little Falls Fibre Co., supra note 102.

104. 280 U.S. 369, 377 (1930).

105. Justice Stone specifically refused to pass upon the contention of the New York Courts that the defendant's liability could be alternatively predicated on the ground that its license to generate power and use flashboards therefor was unrelated to navigation. The later New River case specifically decided otherwise, that the Power Act and licenses issued thereunder are a proper exercise of the navigation power. See text at note 140 infra.

106. Judge Bazelon implied in the instant case (202 F.2d 190, 210 (D.C. Cir. 1952)) that the phrase saving the United States from liability meant that no 
Justice Stone held that the licensee, by accepting the license, had agreed to comply with the section; it required him to pay for property rights of the plaintiff which had been damaged by operation of the project. These rights, he held, had not been destroyed by the Act, instead they were saved by section 27 (which has been previously set forth)..$^{107}$ In this regard, Justice Stone held:

". . We think the interest here asserted by the respondents, so far as the laws of the state are concerned, is a vested right acquired under those laws and so is one expressly saved by Sec. 27 from destruction or appropriation by licensees without compensation ..." 108

This interpretation is in square conflict with that of the FPC and Judge Bazelon, who contended that section 27 saved only water rights connected with irrigation and municipal uses and therefore that other interests in water are not within the compensation provisions of section $14 .^{100}$ It is also true that the Ford interpretation does not conform with the purpose announced for section 27 by its Congressional author, nor did the Court in that case refer to the legislative history of the Act. However, Ford is in accord with the tenor of the Congressional debates which demonstrated an intent to preserve state property rights in water power. ${ }^{110}$ It has been followed in a number of instances which are discussed below.

allowance need be made for water rights even if they must be acquired by a licensee. But $\$ 10(c), 16$ U.S.C. $\$ 803$ (c) (1946), does not specify the types of property for which the United States is not to be liable, so if the Judge's construction is correct, no allowance need be made for any private property which the licensee must acquire. This of course would be an erroneous construction, for certainly the licensee is to be reimbursed for land and buildings that he must acquire for the project. See, e.g., $\$ 14$, 16 U.S.C. $\$ 807$ (1946). Accordingly, a proper construction of the phrase seems to be that at the time of building the project the owner of private property must look to the licensee, not the United States, for compensation, Buchanan v. United States, $78 \mathrm{Ct}$. Cl. 791 (1934), and the phrase has no relation to reimbursement by the United States upon recapture. Cf. Pikes Rapid Power Co. v. Minneapolis, St. P. \& S.S. M. Ry., 99 F.2d 902, 912 (8th Cir. 1938).

107. See text at note 56 supra. On the other hand $\S 10(c)$ does not create a new property right or cause of action; it only protects such property rights as are recognized by applicable state law. Rich Hope Plantation v. South Carolina Public Service Authority, 216 S.C. 500, 522, 59 S.E.2d 132, 141 (1950); Alabama Power Co. v. Smith, 229 Ala. 105, 110, 155 So. 601, 603 (1934); Miller \& Lux Inc. v. San Joaquin Light \& Power Corp., $120 \mathrm{Cal}$. App. 589, 611, 8 P.2d 560, 569 (4th Dist. 1932), aff'd, 8 Cal. 2d 427, 65 P.2d 1289 (1937).

108. 280 U.S. 369,378 (1930).

109. That is, "other uses" at the end of $\$ 27$ refers only to other uses similar to irrigation or municipal uses. See text at note 59 supra.

110. See, e.g., Sen. Rep. No. 179, 65th Cong., 2d Sess. 4 (1917) “. . . the bill is so framed as to protect and maintain the rights of riparian proprietors over and in the beds and waters of those [navigable] streams, and allow the full exercise and enjoyment of the latter, subject to the paramount authority of Congress to regulate the same for navigation purposes." This report dealt with the Senate Bill which was weaker than that passed by the House in that it lacked any equivalent of $\$ 27$ which was placed in the bill by the lower chamber. See also, Statement of Rep. LaFollette, 56 CoNG. Rec. 9108-12 (1918). 
The FPC relied on First Iowa Hydro-Electric Coop. v. FPC, ${ }^{111}$ to support its position that the Power Act destroyed all private water rights except those related to irrigation and municipal uses. There, the law of Iowa would have prevented the applicant for a license from building a dam which diverted waters of the Muscatine River above its juncture with the Mississippi, and returned them to the Mississippi via a canal some distance below the junction. Iowa law would not permit the resultant drying up of the Muscatine between the dam and the River's junction with the Mississippi. ${ }^{112}$ This location of the dam, however, apparently was the only one to which the FPC would give approval. ${ }^{113}$ Nevertheless, the FPC denied the license because of section $9(\mathrm{~b})$ of the Act which provides that a license applicant must submit:

"Satisfactory evidence that [it]. . . has complied with the laws of the State . . . with respect to bed and banks and to the appropriation, diversion and use of water for power purposes . . ."

The Supreme Court reversed, holding that the FPC must exercise its independent judgment as to whether such a diversion of the Muscatine's waters was desirable, and if it decided it was, a dam might be built, regardless of Iowa law. ${ }^{114}$ Justice Burton, writing for the majority ${ }^{116}$ held that neither section 9 (b) nor 27 saved state regulatory legislation. In regard to section 27 he said:

"The effect of Sec. 27 in protecting state laws from supersedure, is limited to laws as to the control, appropriation, use or distribution of water in irrigation or for municipal or other uses of the same nature." 116

111. 328 U.S. 152 (1946).

112. Iowa CoDE $\S 469.5$ (1946) (formerly IOWA CODE c. $363, \S 7767$ (1939)).

113. See, First Iowa Hydro-Electric Coop., 6 F.P.C. 227, 229 (1947).

114. The FPC subsequently granted a license, 6 F.P.C. 227 (1947) and this action was affirmed on appeal, Iowa v. FPC, 178 F.2d 421 (8th Cir.), cert. denied, 339 U.S. 979 (1950). See also, City of Tacoma, 92 P.U.R. (N.S.) 79 (FPC 1951); Portland General Elec. Co. 92 P.U.R. (N.S.) 247 (FPC 1951). Similar problems are found in ICC regulations. See, e.g., Seaboard Air Line Ry. v. Daniel, 333 U.S. 118 (1948).

115. Justice Frankfurter dissented on the ground that the Iowa courts should first construe the pertinent state statute prior to the FPC action on the license application. Since the FPC sought to postpone its decision until Iowa law had been so determined, its refusal of the license should be upheld. See First Iowa Hydro-Electric Coop., 4 F.P.C. 27, 31-2 (1944). However, the FPC appears to have sought a decision in the federal courts on supersedure by the Power Act, rather than an interpretation of state law by the Iowa courts.

116. First Iowa Hydro-Electric Coop. v. FPC, 328 U.S. 152, 175 (1946). To support this statement the early case of Alabama Power Co. v. Gulf Power Co., 283 Fed. 606, 619 (D.C. Ala. 1922) was cited, where the court did apply the rule of ejusdem generis, to construe the phrase "other uses" in section 27 , thus limiting its effect to uses similar to irrigation or municipal uses. That opinion, 
Despite this language, the majority in the instant case, strangely stated that First Iowa when combined with section 27 made ". . . it clear beyond peradventure that Congress did not intend the . . . Act to destroy vested property rights such as those here involved, but only to regulate their exercise." 117

Justice Burton, of course, did not say this. On the other hand, his remarks in First Iowa as to the effect of section 27 are not decisive since they were only dictum. The only reason he referred to section 27 , was to hold that it had no relation to saving or destroying state regulation, rather, "[s]ection 27 expressly 'saves' certain state laws relating to property rights as to use of water . . ."118 The question before the Court then did not involve state property rights, rather it was a case of square conflict between state and federal regulation.

Section 9 (b) was held to permit the FPC to require a license applicant to submit information as to the extent of his compliance with state law; but the section did not prevent issuance of a license to an applicant who had not so complied. This did not mean that such a licensee would not have to comply with any state laws relating to use of water; rather as each question arose, the effect of the Power Act on the state law would be passed upon:

"When this application has been remanded to the Commission, that Commission will not act as a substitute for local authorities having jurisdiction over such questions as the sufficiency of the legal title of the applicant to its riparian rights . . . The references made in 9 (b) to beds and banks of streams, to proprietary rights to divert and use water . . . neither add anything to nor detract anything from the force of the local laws, if any, on these subjects. In so far as those laws have not been superseded by the Federal Power Act, they remain as applicable and effective as they were before its passage." 119

At any rate, prior to First Iowa the Supreme Court had determined in Ford that a licensee must acquire property rights necessary under

however, does not make it clear how this section was applicable to the principal issue before the court, namely the constitutionality of the Power Act. Apparently all the court, which cited no legislative history, held was that section 27 did not bar federal regulation of navigable waters to generate electrical power, even though the state has been or is regulating such activity. Interestingly, the opinion stated (at p. 620) that fishing rights recognized by state law were saved by $\$ 27$, a position recently rejected without discussion by the FPC in the cases cited supra note 114.

117. Niagara Mohawk Power Corp. v. FPC, supra note 1, at 205.

118. First Iowa Hydro-Electric Coop. v. FPC, 328 U.S. 152, 175 (1946) (italics added).

119. Id. at 178. See also Iowa v. FPC, 178 F.2d 421, 427 (8th Cir.), cert. denied, 339 U.S. 979 (1950). 
state law to use the water involved in his project. It is submitted that this decision and cases following it, were not to be silently cast away by the quoted dictum limiting the "saving" power of section 27 . Justice Burton did not cite Ford, or cases which follow it; yet all of them are contrary to the FPC's contention that First Iowa decides that the Act is to be construed as destroying all state property rights in water save those related to irrigation and municipal uses. Further, a ruling that a licensee must pay for state created water rights used by him, does not create any divided authority over water power development, a situation which Justice Burton held the Power Act sought to avoid. ${ }^{120}$ To be sure the cost of development will be somewhat increased by such payments, but this observance of interests long locally recognized is far different from preventing the construction of any dam at all, which would have been the result of a contrary decision in First Iowa. However, in its brief before the Supreme Court, the FPC, for the first time, argues that allowance of the rentals here in issue would run contrary to the purposes of the Power Act: this added cost of water power projects will increase both rates and the recapture price. ${ }^{120 a}$ This argument assumes, as does that of Niagara, that the Act cannot be construed to afford limited recognition of state created water rights coupled with a congruent limit on reimbursement of amounts spent by a licensee therefor. This article sets forth such an intermediate position; it would not lead to an unreasonable increase in project costs or operating expenses.

The interpretation of First Iowa set out above is supported by the later decision in Grand River Dam Authority v. Grand-Hydro, ${ }^{121}$ in which Mr. Justice Burton also wrote the majority opinion. There a licensee condemned in a state court, and under state law (as a state created public utility), a site for a water power project. It was ordered to pay for the value of the land as a power site, that is to pay for the value of the right to use the water appurtenant to the land. The judgment was affirmed by a divided (5-4) Supreme Court. The decision appears based on the grounds that if the licensee chose to condemn under state law, he must pay values allowed by that law. If it had condemned under the power of condemnation given by the Power Act, the result might have been different. Said the majority ". . . we express no opinion upon what would be the appropriate measure of value in a condemnation action brought by

120. Id. at 168.

120a. Brief for Petitioner, p. 24, FPC v. Niagara Mohawk Power Co., U.S. Sup. Ct., Oct. 15, 1953.

121. 335 U.S. 359 (1948). 
the United States or by one of its licensees in reliance upon rights derived under the Federal Power Act." ${ }^{122}$

The obligation of the United States to allow expenditures for water rights in computing "net investment" is indeed an open question. But it does not seem open to question that a licensee must pay something for state created interests in water appropriated by his project. For if First Iowa is to be interpreted as the FPC here urges (and as did the dissenting Justices in Grand River ${ }^{123}$ ) then the Act destroyed all state created interests in water, and in Grand River the condemned lands possessed no special values for use as a water power site since the condemnee lacked a federal license. Yet, this interpretation and conclusion was rejected; Justice Burton held:

". . . It is clear that the Federal Power Act cannot be said to have so far affected the use of this land for a power site as to destroy or otherwise render valueless the owner's right to use it for that purpose. That Act merely has attached conditions to the use of the land for a power site." 124

Therefore, unless Ford and cases following it have been overruled, sub silencio, it seems settled that a licensee has an obligation to pay for private rights in water affected by his project. ${ }^{125}$ The following brief account of the decisions which followed Ford indicates a body of law impressive enough to require direct overruling.

The first case is United States $v$. Central Stockholders' Corp..$^{128}$ There, a licensee had proceeded in the state court to condemn the rights of riparian owners that would be affected by. the dam which it had a license to build. The United States sued to enjoin this proceeding and quiet its alleged title to the waters. It asserted that the licensee needed only its federal license to use the water and unless the state condemnation proceeding was stopped, the Federal Government upon recapture would have to reimburse the licensee for sums it unnecessarily spent for state created water rights. (Of course this is the same argument that the FPC has made in the instant case.) The court refused to enjoin the

122. Id. at 373. This question is involved in the instant case, see text at note 185 et seq. infra.

123. The dissenting opinion was by $\mathrm{Mr}$. Justice Douglas, joined by Justices Black, Murphy and Rutledge. They asserted that the consequence of the decision "is to give private parties an entrenched property interest in the public domain, which the Federal Power Act was designed to defeat." Id. at 376.

124. Id. at 372 .

125. The only question that appears to be open in regard to these cases is the extent to which a licensee must pay for state water rights; that is, does the Power Act provide a special method for their valuation. This article suggests that it does provide such a method, and that compensation is to be limited to the amount to be allowed the licensee for such water rights in determining his net investment.

126. 52 F.2d 322 (9th Cir. 1931). 
licensee's condemnation proceeding. It held that Ford decided that regardless of the fact that the United States itself could have taken the water without compensation, or perhaps delegated this power to a licensee, ${ }^{127}$ it did not do so by the Power Act. ${ }^{128}$ This, it said, was shown by section 10 (c), set forth above. ${ }^{129}$ Held the court:

“. . . The law expressly recognized all private rights established and determined by the law of the state and expressly requires the permittee where it interferes with such rights to compensate the owner therefor." 130

In Great Northern Railway Co. v. Washington Electric Co., ${ }^{131}$ the Supreme Court of Washington in a carefully considered opinion reached a result similar to Ford. The licensee had agreed to reimburse a railway for any damage caused by licensee's dam. But when a flood caused by operation of the dam washed out the railway's tracks the licensee refused to pay the costs of repair. It argued that the tracks rested on fill which was illegally in place because it was an unlicensed obstruction of a navigable stream, to whose waters the licensee had the right of use without compensation for property rights affected. This defense was rejected on the grounds that at least vis $a$ vis the licensee the Power Act did not destroy the property rights the railway had under state law to obstruct the river. ${ }^{132}$ Judgment for the railway was affirmed. ${ }^{133}$

127. Cf. Buchanan v. United States, 78 Ct. Cl. 791 (1934), which was cited by neither the court nor the parties below. In Buchanan, the Government, for navigation purposes, had built a dam on the Ohio River; and the FPC had licensed a private corporation to generate electriciy at the dam by use of flashboards. Relying on Ford, plaintiffs, upper riparian land owners, sued the United States for loss of undeveloped water power. Ford was properly held not applicable for the reason that in Buchanan the defendant was the United States. Its building of the dam was a proper exercise of the navigation power, and under Chandler-Dunbar compensation need not be made for water rights thereby destroyed. These cases point up the difference between the use by the United States or its instrumentality and use by a licensee. If the use is as an instrumentality of the United States compensation appears unnecessary. $C f$. Susquehanna Power Co. v. State Tax Comm'n (No. 1), 283 U.S. 291, 297 (1931) (two cases). Iike Central Stockholders, Buchanain and the other cases cited in this section do not pass on whether or not a licensee's expenditures for water rights need be allowed by the Government in computation of net investment.

128. Necessarily the court also decided that the United States did not have title to the water power rights in question, rather it had only a servitude which had not been exercised by passage of the Power Act. By contrast, in a recent opinion involving the same licensee, the FPC held that the United States had property rights in water power, but this was by reason of ownership of appurtenant lands. Southern California Edison Co., 8 F.P.C. 364 (1949).

129. See text at note 106 supra.

130. United States v. Central Stockholders' Corp., sipra note 126 at 332.

131. 197 Wash. 627, 86 P.2d 208 (1939).

132. This Washington case, not cited by the court or parties below, also rests on the alternative ground that the licensee had by contract with the railroad agreed to make good any damage caused by its project.

133. Accord, Pikes Rapids Power Co. v. Minneapolis St. P. \& S.S.M. Ry. 99 F.2d 902 (8th Cir. 1938). 
In Alabama Power v. McNinch, ${ }^{134}$ the Court of Appeals for the District of Columbia, reversed the FPC and directed it to allow as a project cost, moneys paid to purchase water rights which appear to have borne no relation to irrigation or municipal uses. ${ }^{135}$ This was done without discussion of the possibility that the Act rendered it unnecessary for licensees to acquire and pay for such water rights. ${ }^{136}$ In the same manner in a number of cases the FPC itself has allowed expenditures for water rights not related to irrigation or municipal uses. ${ }^{137}$ And a thorough investigation reveals no case in which it has disallowed any part of a sum paid for land on the grounds that it represented values attributable to the land's use for power purposes, i.e., the right to appurtenant water power.

Besides First Iowa, the FPC relied on two other cases to support its contention that the Power Act destroyed all rights to water power except those given by the federal license. These cases were New River, ${ }^{138}$ and the previously mentioned Niagara Falls ${ }^{139}$ decision. These cases did not deal with the obligation of the licensee to compensate persons who had water rights under state law. They did not cite Ford, or cases following it. They did not pass on the necessity under the Power Act for a licensee to comply with state property or regulatory law. They held only that, by itself, such compliance is not enough, as against the federal government, to maintain a power project in navigable waters. After passage of the Power Act, submission to federal regulation, including licensing, would be required.

New River was the great test case involving the constitutionality of the Power Act. ${ }^{140}$ The Court upheld the Act as a valid exercise of the navigation power. It upheld the requirement that a licensee submit to federal regulation and accept a license prescribed by the Act; it also upheld recapture upon payment of the "net investment" even though that sum might be less than the fair value of project at the time of recapture. Therefore, even though it had complied with all

134. 94 F.2d 601, 616 (D.C. Cir. 1937), cert. denied, 317 U.S. 652 (1942). 135. On remand, the FPC allowed the expenditures, Alabama Power Co., 2 F.P.C. 312 , 318-22 (1940).

136. Judge Bazelon stated that this decision conflicted with his interpretation of late Supreme Court decisions and could not be followed. Niagara Mohawk Power Corp. v. FPC, supra note 1 , at 210.

137. Carolina Power Co., 4 F.P.C. 1110, 1114 (1945); Clarion River Power Co. 1 F.P.C. 269, 298 (1935); Columbia Ry. \& Nav. Co., 1 F.P.C. 78, 86-7 (1933). Cf. East Bay Municipal Dist., 1 F.P.C. 12, 13 (1932). These cases were not cited by the court or parties in the case below.

138. United Ștates v. Appalachian Power Co., 311 U.S. 377 (1940) (New River Power Project).

139. See text at note 47 supra.

140. In an earlier case, New Jersey v. Sargent, 269 U.S. 328 (1926), the Act was challenged but the case was dismissed as presenting an abstract question. 
the applicable property and regulatory provisions of state law, the Appalachian Electric Co. was enjoined from building a dam without obtaining a federal license. But the Court did not pass on whether or not a licensee must satisfy these requirements of state law to use the waters licensed by the FPC.

As related earlier, the Second Circuit Niagara Falls decision held that despite compliance with New York law, Niagara's project was, as against the Federal Government, illegally in place when the Power Act went into effect. Therefore, Niagara had to accept a license based on "original cost," not fair value at the time of licensing. This meant that large sums had to be written out of Niagara's plant accounts since there were amounts paid for the plant in excess of its "original cost."

In the instant case, the FPC relies particularly on the following statement in Judge Learned Hand's opinion:

"When Congress passed the Federal Water Power Act in 1920 ... the petitioner's slate was wiped clean, it stood at discretion, as far as any federal rights of diversion. Congress had absolute power to stop it from taking any water whatever or to impose what terms it chose..."141

Use of the phrase "federal rights of diversion" indicates that Judge Hand recognized that state created rights also existed. He did not hold that the latter rights no longer need be acquired by a licensee. He ruled only that, by themselves, such rights were not enough once the Power Act went into effect. Niagara had to comply with federal regulation and licensing in order to operate its project. This is far different from the FPC interpretation of the case, i.e., that it held that state created rights were totally destroyed, so that a licensee need not compensate persons whose interest in waters are appropriated by his project. If he had intended to reach such a conclusion, Judge Hand probably would have discussed Ford and similar cases as well as sections 10 (c) and 27 of the Act, upon which they rested; he did not do this. ${ }^{142}$

By contrast, Judge Hand was very clear on the point that federal regulation under the Power Act did invalidate part of a transaction valid

141. Niagara Falls Power Co. v. FPC, 137 F.2d 787, 790 (2d Cir. 1943).

142. Conceptually it is true that Judge Hand held that the Power Act partially destroyed state created interests in water; at least to the extent that they were no longer sufficient in and of themselves for their owner to operate a water power project. That ruling does not mean, however, that a stranger who obtains a license need not compensate the owner of state water rights. A similar situation occurs under the Communications Act. One who owns the necessary equipment may not send out programs unless he has a federal license. But an FCC licensee cannot operate a station unless he acquires the necessary equipment in transactions valid under state law. See, Radio Station WOW v. Johnson, 326 U. S. 120 , on remand, 146 Neb. 429, 19 N.W.2d 853 (1945). 
under state law by which Niagara acquired certain properties. This transaction was destroyed or disallowed, for purposes of determining net investment, to the extent that Niagara had paid more than the "original cost" of the properties. This last mentioned ruling illustrates that the court of appeals in the instant case read Judge Hand's opinion too narrowly when it said:

". . . rights acquired from the State of New York necessarily yielded to what the Commission may do only when the regulatory actions of the State and national governments conflict as in the First Iowa case." 143

Certainly New York property law yielded to the "original cost" ruling, a regulatory action of the FPC under the Power Act. ${ }^{144}$

\section{The 1910 International Boundary Treaty and Water Rights}

In the instant case, the FPC alternatively contended before court of appeals that the 1910 Treaty destroyed all state created water rights in the Niagara River. ${ }^{145}$ The majority rejected this contention, and the point was not mentioned in the dissent. It is true that Judge Hand had said:

"The United States was then allotted (by the Treaty) the privilege of diverting within the State of New York from above the Falls 'not exceeding in the aggregate a daily diversion at the rate of twenty thousand cubic feet of water per second'. When Congress set up the Commission with power to issue licenses for the 'utilization of power . . . from ... any of the navigable waters of the United States ... ' the Commission was vested with the distribution of this allotment, and any rights acquired from the State of New York necessarily yielded to what it might do." 146

It is certainly true that regardless of rights possessed under state law, the FPC is the policing agency to insure that not more than 20,000 c.f.s. of water are diverted; and that under the Power Act a federal license is required to divert any water at all. But this does not mean that compensation need not be paid if, in diverting the 20,000 c.f.s., a

143. Niagara Mohawk Power Corp. v. FPC, supra note 1, at 207 (italics added).

144. The majority also attempted to distinguish the opinion on the grounds that the issue before the court was capitalization of assets, whereas the instant case deals with allowance of operating expense. Niagara Mohawk Power Corp. v. FPC, sipra note 1 , at 200 . This distinction lacks substance, for both determinations affect the size of the net investment, that is, to determine this latter figure, the FPC must ascertain both the cost of the project (capitalization of assets) and the amount of money earned by it (receipts less operating expenses). See text following note 147 infra.

145. The FPC based this contention on Niagara Falls Power Co. v. FPC, 137 F.2d 787, 790 (2d Cir. 1943). Commissioner Smith concurred in the FPC decision only because he thought the Second Circuit Niagara Falls decision held that the treaty of 1910 destroyed all state created water rights in the Niagara River. Niagara Falls Power Co., 9 F.P.C. 228, 260-1 (1950).

146. Niagara Falls Power Co. v. FPC, 137 F.2d 787, 790 (2d Cir. 1943). 
licensee appropriates state created water rights. The Treaty itself indicates a desire to avoid destruction of state created rights in that the signatory countries wished:

“ . . . to accomplish this object [of controlling diversion] with the least possible injury to investments which have already been made in construction of power plants on the United States side of the river under grants of authority from the State of New York. ...." 147

Allowance in Determination of Net Investment of a LicenSeE's Expenditure for State Created Interests in Water Power.

We have seen that under the Power Act and the law of New York, Niagara must pay for use of the International and Pettebone water rights. In the court of appeals both the parties and the court largely assumed that the problem of the case ends there and that Niagara's expenditures for water rights are to be either completely allowed or disallowed in determining net investments. This article now seeks to show that the analysis must go further; that a licensee's expenditures for water rights may be only partially allowable. Despite its obligation to acquire state created water rights, there is a limit on the sum a licensee should pay for them. This ceiling is identical with the extent to which the government must allow these expenditures in net investment. Payments above this amount by a licensee are unnecessary and should be disallowed. Finally, it is immaterial whether the expenditures were made to acquire the fee or a fixed term, or whether as in this case a yearly rental was paid. Both methods of payment affect the size of the net investment. If a lump sum was paid, the question is what part is to be allowed as a project cost: if a rental was paid, what part is to be allowed as an operating expense with the remainder to be disallowed and added to earnings.

The FPC Contention:-The FPC contends that no part of a licensee's expenditures for necessary state water rights is to be allowed:

". . . even if it is assumed [contrary to our contentions] that the Federal Power Act did not wipe out state water power rights as between private parties, it does not follow that the Act did not wipe out those rights as between the licensee and the United States and its regulatory agency." 148

In support of this view, the FPC cites Regent of the University System of Georgia v. Carroll. ${ }^{149}$ There, the FCC determined that a contract

147. International Boundary Waters Treaty of 1909, Article V, 36 STAT. 2448, 2450 (1909). See also Article VII of the treaty, id. at 2451.

148. Petition for Certiorari filed by FPC, p. 27, FPC v. Niagara Mohawk Power Corp., 345 U.S. 955 (1953).

149. 338 U.S. 586 (1950). 
whereby a licensee paid out part of its profits to a third party violated the Communications Act. It directed the licensee to repudiate the contract if it wanted to retain or renew its license. This was done, but a judgment awarding damages for breach of contract obtained by the third party in the state court was unanimously affirmed by the Supreme Court. The Court assumed that the contract violated the Communications Act, but besides the fact that the plaintiff was not a party to the FCC proceeding, the Court found that the FCC had no power under the Communications Act to destroy all rights under the contract. Its power was limited to granting or denying a license. It is true that if the FPC proposal quoted above is adopted, the end results of Regents and this case would be similar; Niagara would be liable for appropriation of water rights under state law, but the Federal Government would not recognize this liability in determining net investment. ${ }^{150}$ But first we must examine the provisions of the Power Act which specifically deal with this problem of allowance of expenditures for state water rights. We shall see that unlike the Communications Act, the Power Act does not entirely outlaw or refuse to recognize the state created rights in question.

The Power Act's Provisions For Allowance of Expenditures for Water Rights:-Section 14, which specifies the method of determining the price to be paid upon recapture, requires payment of the "net investment" as defined elsewhere in the Act ${ }^{\mathbf{1 5 1}}$ and further provides that:

"Such net investment shall not include or be affected by the value of any lands, rights of way, or other property of the United States licensed by the Commission under this Act, by the license or by good will, going value or prospective revenues; nor shall the values allowed for water rights, rights of way lands or interests in lands be in excess of the actual reasonable cost thereof at the time of acquisition by the licensee."

Thus on its face, the Power Act allows reimbursement to the licensee for sums he spent to acquire state water rights. ${ }^{152}$ We have seen, contrary to the contention of FPC, that the licensee must pay for any state water right affected by the project, not just those related to irrigation and municipal uses.

150. A similar result occurs in federal tax cases where transactions valid under state law may be disregarded for federal tax purposes. See Note, The Commissioner Unbound, 61 Harv. L. Rev. 1033 (1948).

151. In this connection see note 43 supra.

152. Cf. Remarks of Rep. LaFollette, 56 Cong. Rec. 9111 (1918) : "If the Government desires to become the operator of the plant, we capture by paying actual reasonable cost [of] any land and riparian rights the licensee owns, and the net investment he has made in the plant." 
However, the FPC anticipates that the licensee's obligation may be as broad as we have found it. It suggests that, regardless of the interlocking of sections 14 and 27 , there is some overriding consideration which requires disallowance of water rights expenditures; that the Act places the

"United States in a completely different position from that enjoyed by private parties ... [and the] . . United States is concededly the ultimate owner of all water rights in navigable streams . . . " 153

This statement seems incorrect. We have seen that section 14 requires reimbursement for all state water rights. The United States does not "own" water rights except those which are incident to government owned land. ${ }^{154}$ It has a servitude by which it may control or regulate the use of navigable waters, or use them itself, all without charge. But unless and until it takes such action, state water rights are supreme. It is doubtful that the FPC seriously contends that the United States is a landlord in regard to navigable waters. If it does, it should claim that expenditures for water rights be disallowed under provisions of section 14, excluding from net investment, “ . . . lands, rights of way or other property of the United States licensed by the Commission."

There is no significant legislative history on the extent to which the Government must reimburse a licensee for its required water rights expenditures. ${ }^{155}$ Nor are there judicial decisions directly in point.

However, the Government's position in Central Stockholders appears to support the interpretation of the Act here advanced:

"The government . . . claims in its complaint herein, that any judgment so rendered in the condemnation proceedings, although first paid by the permittee, will subsequently fall upon the government at the expiration of the permit, for the reason that at that time the federal government is authorized to take over the project of the permittee upon payment of a reasonable value thereof which

153. Petition for Certiorari filed by FPC, p. 28, FPC v. Niagara Mohawk Power Corp., 345 U.S. 955 (1953).

154. If it "owned" the water rights, the government would not have lost the International Paper case, International Paper Co. v. United States, 282 U.S. 399 (1931). See, United States v. Central Stockholders' Corp., 52 F.2d 322 (1931). Cf. Susquehanna Co. v. State Tax Comm'n (No. 1), 283 U.S. 291, 297 (1931) (two cases).

155. At one point during consideration of the bill by the House in the 65 th Congress, the limitations of $\$ 14,16$ U.S.C. $\$ 807$ (1946), on allowance of the value of lands and water rights and the exclusion of the value of government property were both eliminated. H.R. REP. No. 715, 65th Cong., 2d Sess. 26, 36 (1918). See, Hearings before Hoise Committee on Water Power, 65th Cong., 2d Sess. 455-6, 6645 (1918). The reason for this is not clear. Apparently, the deletion was rescinded after protests from Representative Ferris, a member of the committee, who, nevertheless, filed a minority report on the bill. See, KERwIN, op. cit. supra note 26, at 228 et seq. 
will probably include expenditures made by the permittee in the acquisition of the alleged [water] rights of the Central Stockholders' Corporation of Vallejo." 156

The existence and nature of the Federal Government's obligation in this respect was specifically left open in Grand River. ${ }^{157}$

\section{Limitation of Allowance for Water Rights}

If the above analysis of the Power Act is correct, the United States must allow in determining "net investment," Niagara's expenditures for water rights. However, section 14 also limits this obligation to the

". . actual reasonable cost [of water rights, lands and rights of way] at the time of their acquisition by the licensee. . . ."

The same limitation applies to lands and rights of way. Accordingly, it appears, and will be assumed in the discussion below, that any amount paid by a licensee for lands which is in fact due to the water rights attached to the lands will be treated the same as amounts paid for severed water rights. However, the FPC appears never to have sought to disallow part of the price paid by a licensee for lands, on the grounds that it represented payment for water rights attached to the land. If the FPC prevails in the Niagara case, which deals only with severed water rights, it may well proceed along this land cost front. ${ }^{158}$

Before passing to a detailed discussion of the limitation "actual reasonable cost," it must be observed that this ceiling imposed on particular items of property necessary for a project, is in addition to the general ceiling imposed on all items of property. The general ceiling is found in section 3(13) which provides that:

156. United States v. Central Stockholders' Corp., 52 F.2d 322, 330 (1931). Cf. United States v. Appalachian Electric Power Co., 311 U.S. 377, 427 (1940): "We assume without deciding that by compulsion of the method of acquisition provided in $\$ 14$ of the Power Act. . . these riparian rights may pass to the United States for less than [fair] value."

157. Grand River Dam Authority v. Grand-Hydro, 335 U.S. 359, 375 (1948).

158. The inconsistency of the FPC record in not proceeding on the land cost front was noted by Commissioner Smith. Niagara Mohawk Power Corp., 9 F.P.C. 228, 252, 261 (1950). The commission itself reluctantly admitted that it had allowed as a project cost, all of the very high prices paid by Niagara for mills similar to Pettebone Cataract, but which were sold with water rights "attached." Probably the high land cost was due to water rights. See, Niagara Mohawk Power Corp., 9 F.P.C. at 252n. (1950). The commission in a recent opinion still apparently recognizes some unexplained difference between acquiring water rights and paying a high price for land because it is useful as a power site. In the Matter of Grand River Dam Authority, CCH FED. UTr. LAw REP. (2d ed.) If 10,753, 10,757 (1953). It might well be improper for a utility to acquire riparian land solely for the water rights; if it did so, only so much of the cost as is attributable to the value of water rights should be allowed in the rate base. The remainder, paid for the fast land qua land, would be excluded as not used in the production of power. Redding v. North Cal. Power Co. P.U.R. 1916F, 801.828 (Cal. Ry. Comm'n. 1916). 
“. . . net investment in a project means the actual legitimate original cost thereof. . . ." 180

This has been construed to signify the cost of the property to the person who first devoted it to public service, or "original cost." 160 Accordingly, the limitation of Section 14 will apply only if the "actual reasonable" cost to a licensee had been less than its "original cost." 101

Allowance of Actual Cost:-For an expenditure to be allowed as an "actual cost," a licensee must have paid out the claimed amount in money or its equivalent in property. Further, it must be paid out in an arms' length transaction to a non-affiliated company. The FPC stated this some time ago when it defined actual cost as that which is:

". . . real and bona fide, as distinguished from fictitious or fabricated, whether by intercorporate dealings or otherwise." 162

There seems no doubt that a licensee can be limited to the "actual cost" of water rights, as defined above, especially in view of the numerous decisions upholding FPC determinations which disallowed claimed project costs, because it was found that they were paid as profits to affiliates or were mere book write-ups. Similarly, the FPC has been upheld in cases where it disallowed amounts actually paid to the extent that they exceeded "original cost." 163

Allowance of Reasonable Cost:-As to the second ceiling, expenditures for water rights, to be allowed, must be "reasonable." This term is neither defined nor mentioned elsewhere in the Act. There is no definition of it in either FPC regulations or in administrative or

159. As previously noted, certain deductions are made from the project cost to determine net investment. See text at note 38 sipra. It is also true that $\$ 14$, 16 U.S.C. $\$ 807$ (1946), itself imposed another general ceiling, for it provides that the price to be paid on recapture shall not exceed the "fair value" of the project, which of course may be less than the net investment.

160. See, e.g., Niagara Falls Power Co. v. FPC, 137 F.2d 787, 794-5 (2d Cir. 1942) ; Louisville Gas \& Electric Co. v. FPC, 129 F.2d 126 (6th Cir. 1942).

161. Strangely, the FPC regulations require the cost of water rights to be recorded at "first cost," a term nowhere defined. 18 CoDE FED. REGs. \&101.3-9(b) (1949).

162. Louisville Hydro Electric Co., 13 FPC ANN. Rep. 307, 314 (1933). The commission was there defining "actual legitimate original cost," term by term. The use of the word "actual" in \$14, 16 U.S.C. $\$ 807$ (1946), may be redundant if it has the same significance in $\$ 3(13), 16$ U.S.C. $\$ 796(1946)$. It is not clear, however, whether the construction $\$ 3(13)$ signifying "original" cost is really only a construction of the words "original cost" or of the entire limitation ("actual legitimate original cost"). Only if it is the latter does the use of "actual" in $\$ 14$ have independent significance. A further indication of the redundancy of "actual" in $\$ 14$ is shown by the fact that the FPC regulations now define cost itself to include only amounts "actually paid" for property. 18 CODE FED. REGS. $\S 101.02-10$ (1949).

163. See note 35 supra. 
judicial decisions. ${ }^{164}$ The legislative history offers no assistance. To achieve a sensible and fair solution we must not only analyze the Power Act with its "hiatuses and inconsistencies," 164a but also the relevant case law.

On its face, the term "reasonable" means that the FPC must exercise its judgment as to what would be the prudent amount for a licensee to pay for water rights; if he paid more than this amount, it should be disallowed, even though the transaction was valid under state law, and he was the first person to devote the water rights to public service. It is submitted that the following types of expenditures, discussed more fully below, should be so disallowed, as unreasonable:

1) Amounts paid by a licensee which are attributable to speculative values; for instance when the seller had insufficient property or financial backing for himself to use the water rights for power generation, but obtained an extraordinarily high price for reasons such as the urgent needs of the licensee.

2) Amounts paid by the licensee which are attributable to the value that the water rights would have after the licensed period has expired. Issuance of a federal license made it unnecessary and therefore unreasonable for a licensee to acquire or pay for water rights attributable to this "remainder."

\section{The Constitutionality of these Interpretations of "Reasonable} Cost":- The interpretations set out above appear to be constitutional and also a proper construction of the Power Act. For the discussion of the constitutional question, the latter will be assumed. Next, the question of construction will be resolved.

Licensees will object that these interpretations may lead to disallowance of amounts paid by them in arm's length transactions, valid under state law. This would take their property without just compensation, whenever "net investment" is used in recapture or rate making.

164. In the Lonisville case, supra note 162 , the commission defined "legitimate" cost, which is part of the general ceiling, as meaning "not coercive, collusive, fraudulent or unreasonable." These meanings make up part of the interpretation of "reasonable cost" here advanced. To that extent the use of "reasonable" in $\$ 14$, 16 U.S.C. $\$ 807$ (1946), is perhaps redundant, i.e., if the FPC insistence on "original cost" is based only upon the last two words in $\$ 3(13), 16$ U.S.C. $\$ 716$ (1946), limiting project costs to the "actual legitimate original cost" of property acquired for the project. In Alabama Power $v$. McNinch, the District of Columbia Circuit indicated that "legitimate" in $\$ 3(13)$ and "reasonable" in $\$ 14$ are synonymous. Alabama Power v. McNinch, 94 F.2d 601, 606, n.3 (D.C. Cir. 1937). See also, Susquehanna Power Co., 4 F.P.C. 74, 121-24 (1944); SEN. REp. No. 621, 74th Cong. 1st Sess. 18 (1935); H.R. REP. 1903, 74th Cong. 1st Sess. 73 (1935). However, the position of this article is not substantially changed even if $\$ 14$ is a redundant statement of $\S 3(13)$. The only change would be that the interpretation of "reasonable cost" advanced here in regard to water rights would also apply to "legitimate cost" as applied to them. See notes 37 and 162 supra.

164a. Metropolitan Edison Co. v. FPC, supra note 37 at 723 . The relation of Section 14 to Sections $3(13)$ and $10(\mathrm{~d})$ is discussed in notes $37,162,164$ supra. 
The cases upholding "original cost" as the measure of project costs, will meet this objection. ${ }^{165}$ There, licensees were uniformly ordered to write out of their project accounts the price that they paid in arms' length transactions to the extent that this price exceeded the "original cost" of the project. This action is much more drastic than the disallowances which result from the definition here proposed. Further, the latter cost would have to be determined by a method which would sharply contrast to the automatic and drastic disallowances made by the original cost cases. That is, an answer could not be reached merely by reference to any set of account books.

True, the proposed method of valuation may be complex and require evaluation of differing expert opinion on the facts of each case. Yet the same approach is used wherever a problem of reasonable value occurs-whether it is in eminent domain, rate, or tax proceedings. Furthermore, simplicity and uniformity of method, desirable as they may be, are less vital than the end of substantial justice which here requires, not an executive or accountant's edict, but case by case adjudication.

The constitutional objection is also met by the fact that the limitation on allowance for water rights is a valid condition of the federal license, to which the licensee has agreed. Imposition of such conditions has been upheld in the past, both in reference to state law and to the very provisions of the Power Act in question. In Fox River Paper Co. v. Railroad Commission ${ }^{168}$ as a condition in the licensing of a dam, the State of Wisconsin provided for recapture by the state upon payment of reproduction costs of the plant at the time of recapture. However, in respect to water rights, the state would pay only their fair value at the time of licensing. The applicant contended that freezing the amount allowed for water rights would deprive it of the true value that the rights might have at the time of recapture, and therefore, violated the Fourteenth Amendment. The Supreme Court disagreed, and held, in an opinion by Justice Stone, that imposition of this condition did not violate the Fourteenth Amendment for it was a proper exercise of the state's sovereign power over waters within the state. Compliance with the condition was " . . . the price which plaintiffs must pay to secure the right to maintain their dam." 167 On these very grounds section 14 of the Power Act, the section here under consideration, was held constitutional in New River. Justice Reed held:

". . . we assume without deciding that by compulsion of the method of acquisition provided in $\S 14$ of the Power Act and the

165. See note 35 supra.

166. 274 U.S. 651 (1927).

167. $I d$. at 657 . 
tendered license, these riparian rights may pass to the United States for less than their value [at the time of recapture]. In our view this 'is the price which [respondents] must pay to secure the right to maintain their dam.' The quoted words are the conclusion of Fox River Paper Co. v. Railroad Commission. The case is decisive on the issue of confiscation . . . The fact that the Fox River case involved a state and this case involves the United States is immaterial from the due process standpoint." 168

Licensees may argue, however, that both Fox River and New River held that a licensee might be denied the fair value of water rights at the time of recapture, but do not support the above position where it is proposed to deny part of the licensee's out of pocket costs. ${ }^{169}$ Again the answer to this is to be found in the "original cost" cases.

The Proposed Interpretation of "Reasonable Cost" as a Proper Construction of the Power Act:-Constitutional objections having been met, we pass to the question of whether the suggested interpretations of "reasonable cost" are in accord with the remainder of the Power Act. Before we do so, it is pertinent to observe that it has been well settled that the United States in furtherance of its navigation power can take over water rights, or prohibit their use, without giving compensation. ${ }^{170}$ Therefore, no payment should be required unless there is specific statutory direction requiring the United States to pay for any state created rights it disturbs. ${ }^{171}$ As explained, the Power

168. United States v. Appalachian Power Co., 311 U.S. 377, 427-8 (1940).

169. Yet no one would deny that it would be proper to pay only the fair value of a project at the time of recapture, even though this value be less than the cost of the project to the licensee. Section 14, 16 U.S.C. $\$ 807$ (1946), provides that fair value be used in such a situation. And in regard to licensees whose use of water was a right vested as against the United States, the fair value as of the date of licensing must be allowed in the recapture price. $\$ 23,16$ U.S.C. $\$ 816$ (1946). This may be constitutionally required. Cf. Monongahela Navigation Co. v. United States, 148 U.S. 312 (1893).

170. See text at note 68 supra.

171. The Reclamation Act of 1902, 32 STAT. 388 (1902), as amended, 43 U.S.C. $\$ 371$ et seq. (1928), illustrates the proposition that when the government is to pay for water rights, Congress can say so. See, United States y. Gerlach Livestock Co., 339 U.S. 725, 734 (1950). Cf. Nebraska v. Wyoming, 325 U.S. 589 (1945). See also, Boulder Canyon Project Act, $\$ \$ 8,13,45$ Stat. 1057, 1062, 1064 (1928); 43 U.S.C. $\$ \$ 617(\mathrm{~g}), 617(1)(1946)$; Arizona v. California, supra note 71 . Section 8 of the Reclamation Act was the model for $\$ 27$ of the Power Act, 16 U.S.C. $\$ 822$ (1946); but, in addition to the words used in $\$ 27$, it contains the following language: "The Secretary of the Interior in carrying out the provisions of this Act, shall proceed in conformity with such [state] laws, and nothing herein shall in anyway affect any right of any State or of the Federal Government or of any landowner, appropriator, or user of water in, to, or from any interstate stream or the waters thereof. . . " Justice Jackson stated in United States $v$. Gerlach Livestock, supra, that the quoted words of $\$ 8,16$ U.S.C. $\$ 801$ (1946), "parallels that [sic] in" the Ford case. But the Ford dictum did not consider the full ramifications of the recapture provisions of the Power Act, nor was the Government a party in that case. A more parallel case is United States v. Central Stockholders' Corp., 52 F.2d 322 (9th Cir. 1931), not cited by the Justice. 
Act substitutes for such payment a system of reimbursement of the licensee of its "reasonable" expenditures for water rights for which it has not been previously reimbursed by consumers. This result should be anticipated by anyone who has acquired water rights since enactment of the Power Act. As to those who purchased water rights prior to the Act, at least the federal servitude and its drastic possibilities were known. ${ }^{172}$ In regard to these early acquisitions one might hope for administrative and judicial sensitivity in applying the principles of valuations suggested here; at least if there was, what Commissioner Smith saw in the Niagara situation, " . . . a bona fide payment at arms length in accordance with the custom and general understanding of the law at that time." 173

(1) Disallowance of amounts paid for speculative values:Amounts paid for speculative values should be disallowed under the Power Act. An analogy can be drawn to condemnation proceedings, where a condemnee is denied values claimed for special use of land if the court finds his claim too fanciful or impossible of achievement. ${ }^{174}$ It seems proper to disallow amounts paid by a licensee for such values as well as for "hold-up" values in a negotiated purchase; the only decision in point has upheld FPC action which did just this. ${ }^{175}$ If an excessive price was demanded by the seller, the licensee should have proceeded to condemn the land or water rights necessary for his project, and thus protected himself from such extortion. ${ }^{178}$ In eminent domain proceedings the condemnee has to demonstrate the special value possessed by his water rights, that is, the kind of use he could have made of them. Unless he had enough property to develop a power site he will not be compensated for value as a power site. ${ }^{177}$

172. E.g., Niagara Falls Power Co. v. FPC, 137 F.2d 787 (2d Cir. 1942); Pennsylvania Water \& Power Co. v. FPC, 123 F.2d 155 (D.C. Cir. 1941), cert. detied, 315 U.S. 806 (1942).

173. Niagara Mohawk Power Corp., 9 F.P.C. 261 (1950). The FPC has recently acted with such sensitivity in Grand River Dam Authority v. Grand-Hydro, 335 U.S. 359, 374 (1948). See text at note 186 infra.

174. Similarly, $\S 14,16$ U.S.C. $\$ 807$ (1946), also prohibits any amount being allowed in net investment for "going value, or prospective revenues" of the project.

175. Alabama Power Co. v. FPC, 136 F.2d 929, 931 (5th Cir, 1943). Cf. Rochester Gas \& Elec. Corp. 63 P.U.R. (N.S.) 501 (N.Y.P.S.C. 1946).

176. Cf. United States v. Chandler-Dunbar Co., 229 U.S. 53, 79-81 (1913). In Ford and Son v. Little Falls Fibre Co., 280 U.S. 369, 379 (1930), the Court commented that it did not pass upon whether or not $\$ 21$, 16 U.S.C. $\$ 814$ (1946), of the Power Act, which gives licensees the power of eminent domain, included the power to condemn water rights such as those involved in that case. Subsequent decisions have assumed that such rights may be condemned, e.g., Grand River Dam Authority v. Grand-Hydro, 335 U.S. 359, 374 (1948). See also, 2 Nichols, Eminent Domarn $\$ 5.79$ et seq. (3d ed. 1950).

177. Compare Grand River Dam Authority v. Grand-Hydro, note 176 supra (compensation allowed) with United States v. Powelson, 319 U.S. 266 (1943) and Continental Land Co. v. United States, 88 F.2d 104 (9th Cir. 1937) (compensa- 
In the case of the International Paper rights, compensation should be given for use of the water in an existing factory or mill, since it is shown that the water has value for this special use. In the case of the Pettebone rights, compensation should be allowed for any extra value that water power may have by reason of having been brought inland. ${ }^{178}$

(2) Disallowance of Amounts Paid for "Remainder":-The second qualification of "reasonable cost" would disallow expenditures attributable to use of water rights beyond the licensed period. This is derived as follows: as far as the Federal Government is concerned, at the time of recapture it need not acquire any state created water rights from the licensee or anyone else. The Power Act does not change this, except that it provides limited reimbursement for amounts that the licensee had to pay out during the period of his license to acquire state water rights necessary for the project. ${ }^{179}$ That is, section 27 of the Act is to be construed as saving state created water rights, vis $a$ vis licensees and other private persons, but these rights were always subject to this federal servitude. Nothing new was added to them by the Power Act.

The application of this interpretation to a licensee who has purchased the fee to water rights, is clear. The value of the use of the

tion not allowed). It should be noted that these comments do not deal with condemnation by the United States under its navigation power; under that power no value may be allowed for power site use since the Government has appropriated the use by the condemnation and need not compensate except for the land as ordinary land. E.g. United States v. Washington Water Power Co., 41 F. Supp. 119 (D.C. Wash. 1941), aff'd, 135 F.2d 541 (9th Cir.), cert. denied, 320 U.S. 747 (1943). The Federal Power Act, however, appears to have required the licensee to pay compensation for feasible power site use and the United States is to reimburse therefor.

178. It might be questioned whether these uses of water power would be efficient enough to be of any value in light of the cheap electricity available to International and Pettebone. There is another interesting question concerning both the International and Pettebone rights: whether or not any allowance made for them should be based on the cost to their respective grantors, both of whom were predecessors of the present licensee (the original Niagara Falls Power Co. and the Hydraulic Canal Co.). Both predecessors might be held to have devoted these water rights to the public service. Their cost therefore would be the "original cost," the general ceiling upon all allowances. The FPC decision (and consequently the court of appeals) did not consider the possibility of such a result-disregarding the intervening withdrawal from public to private use. To do so would seem harshly retroactive unless the intervening transactions were a sham to raise values. This does not appear to be the case with the International and Pettebone companies, both of whom installed machinery in their plants for some years prior to returning use of the water rights to Niagara.

179. Cf. United States ex rel. Chapman v. FPC, 345 U.S. 153, 170 (1953). Reimbursement, of course, depends upon the licensee not having been reimbursed by consumers for the water rights, by having included in the rates a charge for their exhaustion. Wherever the consumers have paid for project property, their contribution will be deducted from the otherwise allowable cost of the project. See text at note 40 supra. See also discussion of Buchanan case note 127 supra. 
water rights over the license period should be subtracted from the cost of the fee. This value is the "present value" computed as of the date that the fee was purchased. ${ }^{180}$ The difference will be the amount to be disallowed and should be set up as a reserve against the cost of the fee. ${ }^{181}$

In the case of licensees such as Niagara, who have rented, not purchased, water rights, the solution is more complex. The United States should reimburse a licensee for rentals to the extent that they are allowed as an operating expense; for in that way the rentals cannot be held part of (excessive) earnings which reduce the net investment or recapture price. But how can a rental be anything but an operating expense, especially when paid to a third party in an arm's length transaction? The licensee will have purchased no right to use the water beyond the licensed period. Usually such a rental will be allowed, in toto, as an operating expense. Yet a landlord, realizing that his right to water will cease without compensation, upon recapture, may "load" rentals with an increment designed to compensate for the value of the remainder that he would realize upon, but for the federal recapture. If that is the case, so much of the rentals that represent such increment, must be disallowed. ${ }^{182}$ The licensee should not have paid this amount, he could and should have protected himself by condemnation of the rights for the license period.

180. This is provided by the Act, for $\$ 14,16$ U.S.C. $\$ 807$ (1946), says that the "actual reasonable cost" is to be as of the "time of acquisition by the licensee." This presents no problem in the case of water rights purchased after enactment of the Act. See, United States v. Washington Water Power Co., note 177 supra. What of rights purchased before that date? Since the entire purchase price could be rendered worthless in the discretion of the federal government, it does not seem unjust to restrict reimbursement for the fee to the value of fifty years use as of the date of the license. Admittedly this is a rough and ready rule, but it is also a fair and consistent application of the Act. The alternative, of course, is to hold that since it could not be anticipated that the water rights had only a limited life, the full purchase price of the fee will be allowed to the extent that it does not include speculative values.

181. Perhaps, the reserve should be written off immediately or over a limited period, to a surplus account. So much of the property account as is allowed in net investment should not, however, be treated as a wasting asset since the licensee will receive the full book value at the end of the licensed period. Therefore even though these water rights are diminishing in value each year, this diminution cannot be charged to earnings for it will all come back in one lump sum payment at the end of the license. That substantial sums may be paid for the "remainder" is illustrated by the instant case, see note 196 infra. For instance, if the nonspeculative value of the fee to water rights is $\$ 1,000,000$, at the normal rate of return for utility property, $6 \%, \$ 60,000$ a year will be a fair rental. The present (or lump sum) value of $\$ 60,000$ a year, payable semi-annually, for the licensed period is about $\$ 950,000$. Thus, under the interpretation here advanced, only $\$ 950,000$, not $\$ 1,000,000$ should be paid and allowed for water rights. This $5 \%$ differential is not inconsequential in the field of utility regulation. (The computation of present value, made in this note and succeeding ones, were made with the aid of the annuity tables found in PATON, AccountanT's HANDBOoK, 1144-5 (3d ed. 1945)).

182. In regard to leases, such as the International one, executed before the Act went into effect, we have no "loading" problem. See note 15 supra. Since 
The amortization reserve, required by section $10(\mathrm{~d})$ of the Act ${ }^{183}$ and the cause of the present litigation, is designed to inform the licensee's security-holders that earnings made before as well as after twenty years of operation are being understated in the amount by which water rentals are excessive. The reserve notifies them that upon recapture this excess expenditure for water rights will be added to earnings of the project and will be deducted from the project cost to determine the recapture price. ${ }^{184}$ Of course, under sound accounting practice, such a reserve should be maintained from the start of the licensed period; but the Power Act does not give the FPC power to insist upon it until after 20 years of operation when the amortization reserve is to be created.

\section{Effect of "Actual, Reasonable Cost" Limitation}

Condemnation Proceedings:-At this point the licensees may suggest that even if the above conclusions are correct, the condemnation court may not follow them but will instead decree payment both for speculative values and for use of the water rights beyond the licensed period; disallowance of such compulsory expenditures would be unfair. Grand River indicated that such a result might occur if the condemnation proceeding were brought in a state court under the state law of eminent domain. That is, the Supreme Court would not disturb its judgment decreeing compensation for such values, yet the FPC would not be forced to respect the award in a rate or recapture proceeding. ${ }^{185}$

the Act had not been passed at the time of the lease the landlord would not have suspected that his water rights would become worthless at the expiration of the license. Accordingly he would not "load" his rental with an increment to compensate for the destruction. Nevertheless, at the time the International lease was executed it was pretty well known what form the Power Act would take; hence it should be determined if there was such loading. See text at note 196 infra.

183. This section is set out in note 41 supra.

184. This assumes that earnings over the license period will be excessive. Because this is a contingency, the Act specifies that only a proportion of earnings in excess of a specified per cent (usually $6 \%$ ) be placed in the reserve. In Niagara's case it is one-half. This prevents tying up too much money that may eventually not be found to be excessive earnings, and, at the same time, warns the security holders about the situation. Actually, the reserve is not needed as security by the United States, for the latter merely subtracts excessive earnings from the cost of the plant to determine net investment or the recapture price. It is hard to imagine how earnings could be so excessive as to exceed the cost of the plant. Yet, since depreciation charges may be included in "earnings," see note 40 supra, the price upon recapture might be substantially less than the original cost of the project. Cf. Safe Harbor Water Power Corp. v. FPC, 179 F.2d 179 (3d Cir. 1949), cert. denied, 339 U.S. 957 (1950).

185. "As to the question whether the Federal Power Act should be interpreted as actually superseding the state law of condemnation and as restricting the measure of valuation which lawfully may be used by the courts of Oklahoma in a condemnation action for the acquisition of land for power site purposes by an agency of that State [who was also a licensee under the Power Act], there is nothing in the Federal Power Act to indicate that [such] an attempt has been made by Congress to make such a nationwide change in State law." Grand River Dam Authority y. Grand-Hydro, 335 U.S. 359, 374 (1948). 
However, in a recent opinion fixing the allowable cost of the Grand River lands, the FPC has wisely allowed the full price paid by the licensee whom it refused to penalize for the unforeseen outcome of condemnation proceedings in the state court. ${ }^{186}$ But the tenor of its opinion indicated that similar results in the future will not be dealt with as sympathetically.

In Grand River the Court did not pass on what should be the measure of value in event a licensee seeks to condemn in the federal court. $^{187}$ If this forum is used, the Supreme Court will be free to pass on the method of valuation of the condemned property. A licensee who condemns the fee to water rights should have to pay only the value of the use of the rights for the licensed period. Issuance of the license, in effect decrees that the condemnee's right to compensation for use of the water will cease at the expiration of the license, since the federal servitude will then be exercised.

If the United States Does Not Recapture:-The above interpretation of "actual reasonable cost" of water rights also seems to apply if the United States instead of recapturing, issues a new license to the original licensee or to a third party, pursuant to section 15 of the Act. ${ }^{188}$ But even if this conclusion be incorrect, conservative accounting requires that the licensee prepare for the worst-federal recapture. This means that if the fee has been purchased, a reserve must be set up against its cost, and that reserves also be created in the rental situation.

In the event that a third party takes over the project, the Act states that he has the same rights and liabilities as the United States; section 15 requires him to pay "... such amount and assume such contracts as the United States is required to do in the manner specified in Section 14." Therefore, for purposes of taking over the project, the new licensee appears to be a federal instrumentality exercising the federal servitude over navigable waters; but at the same time he must make the identical reimbursement for past expenditures for water rights as would the Federal Government. That is, they both pay the original

186. In the Matter of Grand River Dam Authority, CCH FED. UTIL. LAw REP. (2d ed.) $\Uparrow 10,753$ (1953). Again it is pertinent to observe that the FPC here allowed as a "reasonable" cost of land, a value which can be traced only to water rights. Yet, in this very opinion, it distinguished its Niagara Mohaze decision as referring only to severed water rights which a licensee need not acquire, whereas the licensee must obtain fast land upon which to locate its project. This seems to be an artificial distinction in view of the way $\$ 14,16$ U.S.C. $\$ 807$ (1946) applies the same standard, "actual reasonable" cost, to allowance of amounts paid for both lands and water rights. True, a licensee must acquire fast land, but if the FPC is correct in its Niagara Mohazw decision, a licensee must not be allowed any sum it paid out which is attributable to water rights, severed or not. See note 158 supra.

187. Grand River Dam Authority v. Grand-Hydro, 335 U.S. 359, 370-2 (1948).

188. Of course this question has not yet arisen since no license issued under the Act will expire until 1971. 
licensee his net investment, the size of which is diminished by any excessive expenditures made for water rights either in purchasing the fee, or renting the rights. Insofar as any landlord is concerned, his water rights are lost by this exercise of the federal servitude.

The same conclusions appear to be true if the original licensee were to continue to operate the project. The Act provides that at the end of the licensed period, until a new license is issued, " . . . the Commission shall issue from year to year an annual license to the then licensee under the terms and conditions of the original license until the property is taken over or a new license is issued." ${ }^{189}$ If a new license is issued to the original licensee, it is to be, " . . . upon such terms as may be authorized or required under the then existing laws and regulations. . . ." 190 The Act does not further clarify the quoted provisions, nor does the legislative history. Apparently their significance was to be left to the courts. ${ }^{191}$ The most sensible interpretation would be that the original licensee should be subject to the same terms as a third party who receives the license and takes over the project. This means that his "net investment" will contain only the "actual reasonable cost" of water rights. In the case of (original) licensees who have purchased a fee to the water rights this will be "actual reasonable cost" of the fee. In respect to those such as Niagara, who have paid rentals this means: (1) their net investment will be reduced by excessive rentals they have paid; and (2) they should cease to pay rentals when the license expires.

Perhaps the above construction of section 15 is incorrect, and private rights in water power continue if there is no recapture. Then the original licensee who has purchased the fee may upon expiration of the license add to its property account an amount equal to the value for the water rights it will use during the period of the new license. If it has been renting the rights it will continue to pay rentals and be allowed the "reasonable" value thereof as an operating expense. In the case of a third party taking over the project, the result would be about the same. If the original licensee had acquired the fee to the water rights, the third party could acquire it upon payment of its "original cost" less any speculative values. Or it could acquire just the use of the rights for the licensed period. If the original licensee had been renting the water rights, the new licensee could continue this practice by paying a "reasonable" rental. But even in this situation,

189. Section 15, 16 U.S.C. $\$ 808$ (1946).

190. Ibid.

191. Congress' principal concern was to insure that the original licensee would continue to remain subject to the Power Act. See, KerwIN, op. cit. supra note 26, at 260 . 
any "unreasonable" expenditures for water rights by the original licensee will not be included in the "net investment," which is also the purchase price for the new licensee. Although under this assumption the new licensee must continue to respect state water rights, it need not pay for its predecessor's mistakes-the original licensee should have protected itself from making these expenditures by condemnation.

However, as mentioned at the outset of this section, regardless of the decision as to status of water rights; if the United States does not recapture, conservative accounting requires that a licensee keep its accounts on the basis of possible federal recapture, for it represents the least possible value it may receive from its expenditures for water rights.

\section{What Should Be Done If the Niagara Case Is Remanded}

Below is a summary of how the construction of the Power Act developed above might be applied to the Niagara case.

International's Rights:- 'The FPC should determine what would have been a reasonable annual rental in 1919 when the original lease of these rights was executed. ${ }^{192}$ This sum should be compared to the $\$ 99,000$ annual rental paid by Niagara as electricity rebates until 1937, and in cash since that time. If the reasonable rental measured as of 1920 was less than what it did pay, Niagara should add the difference to its earned surplus, since its past earnings have been understated by this amount. But since this amount has already been paid to International as a current expense of a past period, it is not available for dividends and the like. Therefore, a special contra account or reserve should be set up against it to indicate this situation. It would not seem to be proper to set up such a contra account on the asset side of the balance sheet since this money had been paid out for a past period, and has no prospective usefulness, as would expenses in floating security issues or organization expenses. ${ }^{193}$

For the years since 1941, special provisions apply. That is, the. FPC has directed that one-half of Niagara's earnings in excess of $6 \%$ made since 1941 be placed in the Amortization Reserve required by the Act. This means that one-half of the excessive rentals paid since 1941 must be added to this reserve which is credited against the cost of the project in determining net investment; provided, of course, earn-

192. The 1937 agreement, discussed in note 20 supra between Niagara and International changing the rental from a rebate on electricity to a flat sum, did not
extinguish the basic obligation entered into in 1919 .

193. See, Baker, Debt, Discount and Expense, 64 HARv. L. REv. 417 (1951). 
ings for the entire licensed period are found excessive. It is true that these requirements of the amortization reserve are less stringent than those suggested here, but conservative accounting which truly reflects the security holder's interest in the enterprise would seem to require the accounting set forth above. ${ }^{194}$

Pettebone Rights:- The rentals paid for the Pettebone rights should be treated in the same manner as the International rentals. That is, the difference between the reasonable rental as of the date of the lease-1925-and the $\$ 37,800$ a year in rebated electric charges, ${ }^{195}$ should be placed in a reserve against earned surplus. In 1947, Niagara purchased the fee to the Pettebone rights for $\$ 728,415.48$. The FPC should determine if this sum exceeded the reasonable value of the water rights at that time. ${ }^{196}$ This determination should be made in accord with the principles outlined above, keeping in mind that compensation for use of the Pettebone rights need not be paid after 1971 when Niagara's license will expire. To the extent that the price paid by Niagara was unreasonable, it should be placed in a reserve account to offset the property account which reflects ownership of the water rights. ${ }^{197}$ On the right hand side of the balance sheet, earned surplus should be reduced by this amount. This will show how much of the purchase price is allowable as part of Niagara's net investment.

Courses of Action Open to Niagara:-Finally we should consider what alternatives the above solution leaves to Niagara other than

194. It might be contended that $\$ \$ 301,304$ of the Power Act, (16 U.S.C. $\$ \S 825$, 825(c) (1946) ), would prevent Niagara from maintaining the conservative reserve here suggested. This section gives the FPC power to prescribe uniform accounts for licensees. See Kripke, supra note 34, at 433; Shapiro, The Effect of Federal Pozver Commission Accounting Orders on Dividend Legality, 59 Y ALE L.J. 597 (1950). However, it is difficult to see why the FPC should complain of undue conservatism on the part of Niagara, as long as the rate payers are not being charged therefor.

195. Niagara Mohawk Power Corp. v. FPC, supra note 1, at 197.

196. Since the seller of the water rights, Buffalo Niagara, and the buyer, Niagara, were affiliated (see notes 23 and 24 supra) perhaps the allowance in net investment should be limited to the reasonable value of the water rights in 1925 when the seller acquired them, if that figure is lower than their reasonable value upon Niagara's acquisition in 1943 . If the $\$ 37,800$ rental is capitalized at $6 \%$, payable semi-annually, the value of the water rights in 1925 for the then remaining 46 years of the license was about $\$ 590,000$ or about $\$ 135,000$ less than Buffalo Niagara paid for them. The latter's purchase price of $\$ 725,000$ represents a present value as of 1925 determined by capitalizing the $\$ 37,800$ rental at $41 / 2 \%$ payable semiannually.

197. In 1947 Niagara's license had 28 years to run. At $6 \%$, payable semiannually, the then present value of Niagara's $\$ 37,800$ annual rental of the water rights, amounted to about $\$ 478,000$. or about $\$ 250,000$ less than the purchase price of the fee for the rights. The difference is attributable either to the unnecessary "remainder," or to an increase in the price level between 1925 and 1947. If the latter, guaere: was it "reasonable," in the $\$ 14$ sense, for Niagara to have acquired the fee? It should be noted in this connection that the purchase price paid by Niagara represents a present value in 1943, of the annual rental to be paid until 1971, determined at somewhat less than $21 / 2 \%$ payable semi-anually. This is an unusually low rate of return for utility property. 
charging its stockholders, i.e., a surplus account, for these excessive expenditures for water rights. In regard to the purchase of the fee to the Pettebone rights, there is probably no other course.

In regard to the International rights, several courses of action present themselves: Niagara might stop paying rentals to International, but continue to use the water. International could seek an injunction to stop Niagara's use of the water or seek contract damages. Either suit should be successful for we have seen that even though International's right to the water terminates in 1971, until then under New York law and the Power Act, Niagara must give compensation if it uses the water. In assessing damages, the court should award only the "reasonable" value of the water rights determined as indicated above. ${ }^{198}$ In effect this would be a condemnation proceeding for the years covered by the suit. This suggests the second alternative, that Niagara condemn or purchase the fee to water rights, paying the non-speculative value of their use until $1971 .^{199}$

However, the above alternatives might subject Niagara to a far greater loss than would result from continuing to pay under the existing lease, because today's price level is much higher than that of 1919 when the lease was executed. On the other hand, a condemnation court might consider certain factors which limit the value of International's water rights. They become valueless in 1971. In the intervening period the use of the water rights by anyone other than Niagara is impractical because of the two factors: the difficulty of obtaining the necessary license, ${ }^{200}$ and the expense involved in reestablishing the International plant.

198. The conclusions stated here, of course, depend upon the conclusion that the taking over of the project by a new licensee or continued operation by Niagara, would not be different from the United States recapturing. See text at note 188 et seq. supra.

199. If the price levels were the same, the present value, at $6 \%$ payable semiannually, of a rental of $\$ 99,000$ a year for the remaining eighteen years of Niagara's license (1953-1971) would amount to about $\$ 1,080,000$. This compares to a present value at the same rate, for the fifty year use in 1921, of about $\$ 1,565,000$.

200. Niagara is licensed to divert all but 275 c.f.s. of the water that may be diverted from the United States side of the River under the Treaty of 1909. 36 STAT. 2448 (1909). Even if Niagara's license did not cover the water that International would seek to use, the FPC might deny International a license on the ground that its use of water would be inefficient. See notes 18,178 supra. This is similar to the situation in the Radio Station WOW case, note 142 supra, where the party with the FCC license was held to lack title under state law to the transmitting facilities; the owner lacked an FCC license. Apparently, the impasse was resolved by a settlement between the parties which was approved by the FCC. Radio Station WOW, Inc., 11 F.C.C. 1450 (1946). A similar outcome could be hoped for in the instant case. But in any case the lack of a license does not deprive the International water rights of all value. It will be recalled that the plaintiff in the Ford case, note 103 supra, recovered its judgment although it lacked an FPC license. 